\title{
Role of PARP in TNBC: Mechanism of Inhibition, Clinical Applications, and Resistance
}

\author{
Desh Deepak Singh ${ }^{1}\left(\mathbb{D}\right.$, Amna Parveen ${ }^{2, *}$ and Dharmendra Kumar Yadav ${ }^{2, *}$ (D) \\ 1 Amity Institute of Biotechnology, Amity University Rajasthan, Jaipur 303002, India; ddsbms@gmail.com \\ 2 College of Pharmacy, Gachon University of Medicine and Science, Hambakmoeiro 191, Yeonsu-gu, \\ Incheon 21924, Korea \\ * Correspondence: amnaparvin@gmail.com (A.P.); dharmendra30oct@gmail.com (D.K.Y.); \\ Tel.: +82-32-820-4948 (D.K.Y.)
}

Citation: Singh, D.D.; Parveen, A.; Yadav, D.K. Role of PARP in TNBC: Mechanism of Inhibition, Clinical Applications, and Resistance. Biomedicines 2021, 9, 1512. https://doi.org/10.3390/ biomedicines 9111512

Academic Editor: Agata Grazia D'Amico

Received: 6 September 2021 Accepted: 18 October 2021 Published: 21 October 2021

Publisher's Note: MDPI stays neutral with regard to jurisdictional claims in published maps and institutional affiliations.

Copyright: (c) 2021 by the authors. Licensee MDPI, Basel, Switzerland. This article is an open access article distributed under the terms and conditions of the Creative Commons Attribution (CC BY) license (https:// creativecommons.org/licenses/by/ $4.0 /)$.

\begin{abstract}
Triple-negative breast cancer is a combative cancer type with a highly inflated histological grade that leads to poor theragnostic value. Gene, protein, and receptor-specific targets have shown effective clinical outcomes in patients with TNBC. Cells are frequently exposed to DNA-damaging agents. DNA damage is repaired by multiple pathways; accumulations of mutations occur due to damage to one or more pathways and lead to alterations in normal cellular mechanisms, which lead to development of tumors. Advances in target-specific cancer therapies have shown significant momentum; most treatment options cause off-target toxicity and side effects on healthy tissues. PARP (poly(ADP-ribose) polymerase) is a major protein and is involved in DNA repair pathways, base excision repair (BER) mechanisms, homologous recombination (HR), and nonhomologous endjoining (NEJ) deficiency-based repair mechanisms. DNA damage repair deficits cause an increased risk of tumor formation. Inhibitors of PARP favorably kill cancer cells in BRCA-mutations. For a few years, PARPi has shown promising activity as a chemotherapeutic agent in BRCA1- or BRCA2associated breast cancers, and in combination with chemotherapy in triple-negative breast cancer. This review covers the current results of clinical trials testing and future directions for the field of PARP inhibitor development.
\end{abstract}

Keywords: breast cancer; PARP (poly(ADP-ribose) polymerase); TNBC; therapeutic target; DNA damage repair; signaling pathway

\section{Introduction}

Breast cancer (BC) is the most common cancer that occurs in women worldwide [1]. $\mathrm{BC}$ is caused by accumulation of somatic mutations in breast cells, which impair cell division and DNA repair mechanisms, resulting in irregular cell growth proliferation, differentiation, and ultimately, progression of tumorigenesis [2,3]. Triple-negative breast cancer is more belligerent and has a poorer prognosis than other types of breast cancer. Triple-negative breast cancer (TNBC) accounts for approximately $15 \%$ of all BC, and lacks human epidermal growth factor receptor 2 (HER2), progesterone receptor (PR), and estrogen receptor (ER) expression and amplification. If we compare it with another type of BC, TNBC exhibits inherently aggressive clinical symptoms and poorer clinical outcomes [4-7]. Presently, the clinical targeted drugs for BC include poly-(ADP)-ribose polymerase (PARP) inhibitors (PARPi), CDK4/6 inhibitors (CDK4/6i), PI3K inhibitors, and AKT inhibitors-but none of these drugs alone are very effective against TNBC [8]. There is an urgent need for the rational exploration of drug compatibility and potential targets for TNBC [7,8]. PARP1 (poly (ADP-ribose) polymerase 1) was discovered approximately 50 years ago and is involved in gene transcription, DNA repair, and cell death [9]. PARP1 has acceptable therapeutic importance against cancer, as shown in Figures 1 and 2 [10]. PARP inhibitors have emerged as effective treatments in clinical trials for sporadic TNBC and $B R C A$-associated cancers [11]. There are various types of PARP inhibitors under clinical 
trial such as olaparib, BSI-201, talazoparib, rucaparib veliparib, and niraparib [10,11]. Inhibition of the PARP-1 and PARP-2 enzymes is believed to be attained mainly via binding of the NAD+ catalytic domain side chain, extending out of the NAD catalytic site of the PARP inhibitor [12]. It also thought that the PARP enzyme locks on to the site of DNA damage, preventing its usual release from DNA molecules [10-15]. PARP-1 binds to the damaged site through its zinc-finger domains in the presence of SS (single-stranded)-DNA breaks [13]. PARP-1 and poly (ADP) polymerization recruits and binds other DNA-repair proteins, leading under normal cell physiology to an increasingly negative charge on the enzyme, and eventual dissociation from the DNA [14]. Some clinical investigations have shown the need for HRD (homologous recombination DNA repair) in facilitating PARP inhibition, via loss of $B R C A$ function $[16,17]$. Researchers from the field have suggested that PARP inhibition is associated with the induction of DNA damage by chemotherapy in the more general cohort of TNBC.

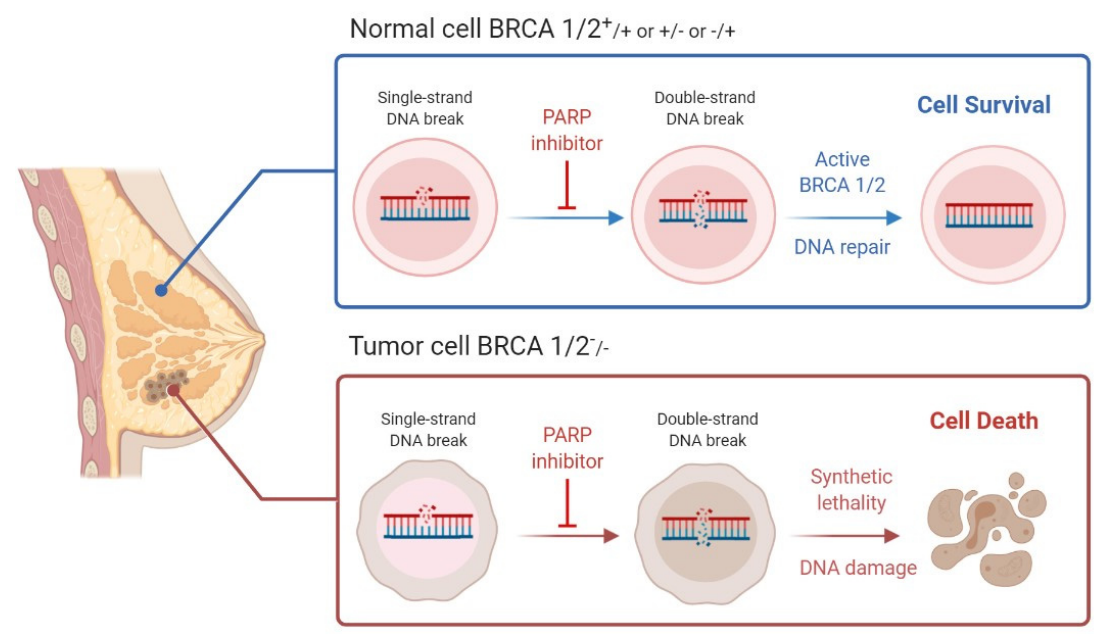

PARP inhibitors: Treatment for BRCA mutant Breast Cancer

Figure 1. Role of PARP inhibitors in treatments for BRCA mutant breast cancer.

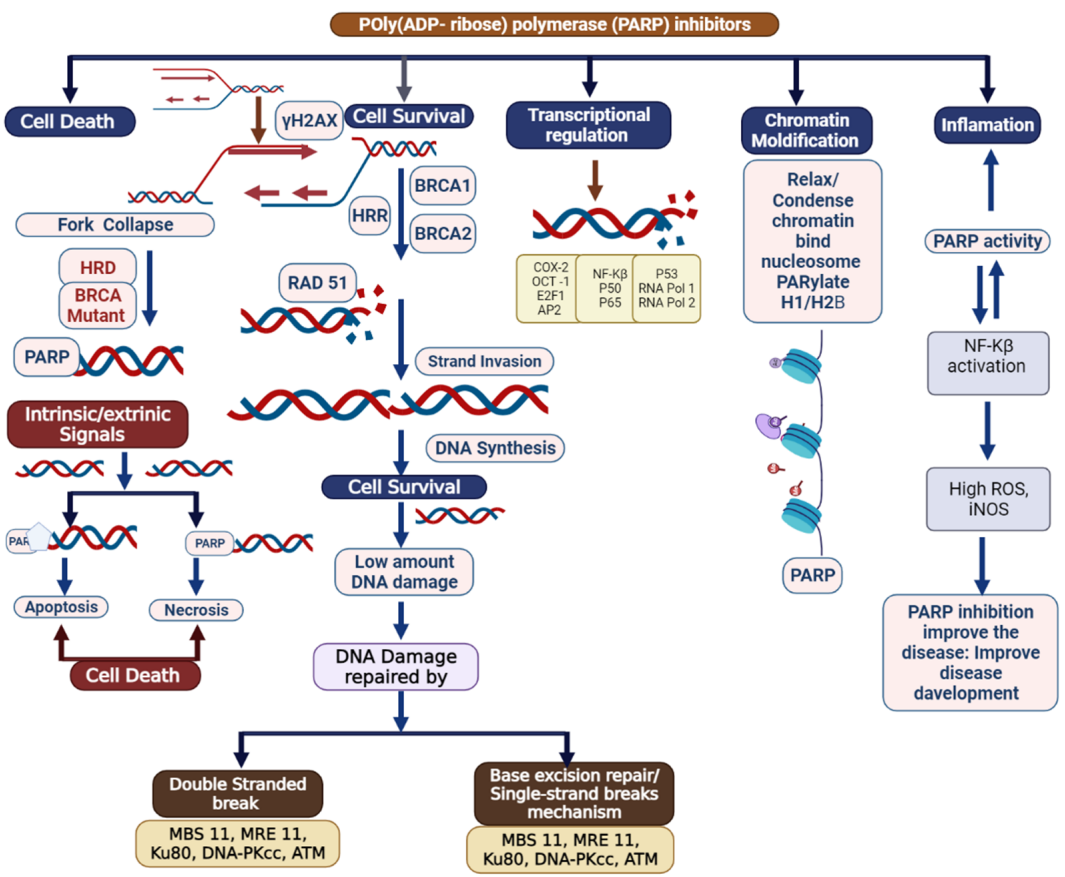

Figure 2. Schematic delineating the multifaceted nature of poly (ADP) ribose polymerase (PARP): 
DNA repair, chromatin modification, inflammation, transcriptional regulation, and cell death. Potential role of elevated PARP-1 in tumorigenesis. After DNA damage, PARP-1 activates DNA repair. However, PARP-1 also acts as a co-activator of NFkB signaling, which can propagate inflammatory signaling and lead to more DNA damage, including the formation of oxidatively clustered DNA lesions (OCDLs). The formation of OCDLs is elevated in numerous tumor types. PARP-1 activity could potentially be beneficial or harmful in the repair of ROS-induced DNA lesions.

\section{Mechanism of Poly (ADP-Ribose) Polymerase Inhibition}

PARP1 is associated with a superfamily of ADP-ribosylating enzymes (ADPRE); it acts as a catalyst for the transfer of ADP-ribose residues from NAD+ onto target substrates, constructing a chain of poly((ADP-ribose); PAR) $[17,18]$. The formation of PAR chains occurs commonly in eukaryotic cells [17]. ADPRE consists of the PARP1 homology protein, which is also produced by the catalytic activity of ADP-ribosyl transferase reactions [19]. The PARP family has approximately 17 members; a few of them (PARP1, PARP2, PARP5A, and PARP5B) are synthesized 1-3PAR chains [11]. Usually, enzymes from this family produce single ADP-ribose units called MARs (mono (ADP-ribosyl)ases) [18,19]. A researcher in this field has found that PARP1 is actively involved in DNA repair and has shown an association of it with nuclear enzymes and chromatin, as shown in Figures 2-4 [20].

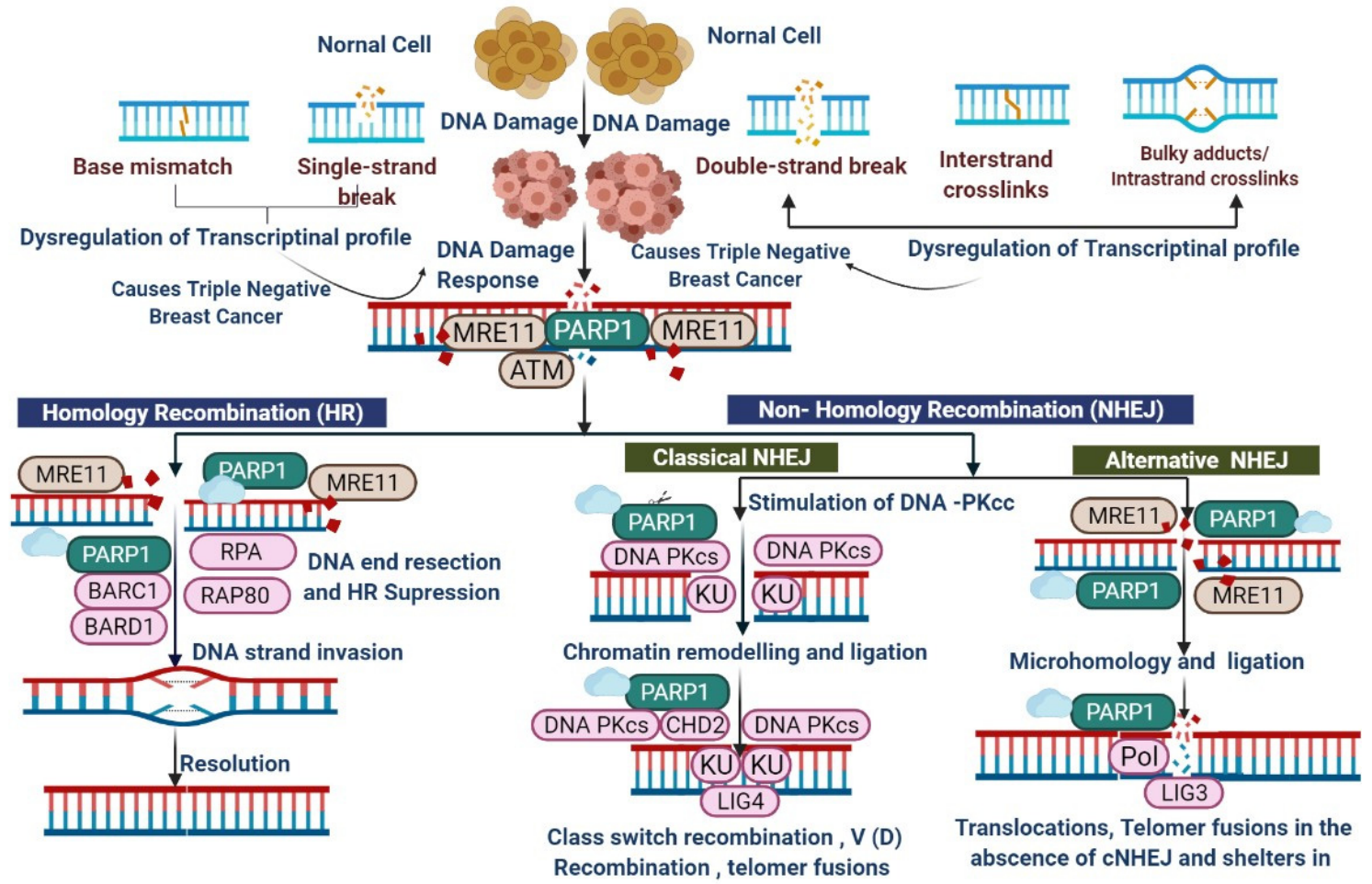

Figure 3. PARP1 is required for the robust detection of DNA double-strand breaks (DSBs) and for the initial DNA damage response through its interaction with MRE11 (meiotic recombination 11) and the apical checkpoint kinase ATM (ataxia telangiectasia mutated). PARP1 has a role in DNA end resection during the HR process through the recruitment of MRE11 to DSBs, which is followed by binding of the single strand by replication protein A (RPA); the reaction is carried out with BRCA1-associated BARD1 (RING domain protein 1). PARP1 also actively participates in DSB repair by activating NHEJ. When DSBs are directed for repair by cNHEJ, they are mediated by KU70KU80 dimers, which trigger DNA-PKcs (DNA-dependent protein kinase catalytic subunits). PARP1 interacts with DNA-PKcs and activates them without the requirement of KU proteins. PARP1 also plays an important role in chromatin remodeling during cNHEJ by facilitating the recruitment of CHD2 (chromodomain helicase DNA-binding protein 2), which then activates XRCC4 (X-ray repair cross-complementing protein 4) and LIG4 (DNA ligase 4) for DNA ligation. PARP1 has a role in alternative NHEJ (aNHEJ), which is active in the absence of cNHEJ. aNHEJ requires the processing of DNA ends by MRE11, which is recruited by PARP1. The resected ends are then joined through sequence microhomology, and the gap is filled by Pol theta (DNA polymerase $\theta$ ) and ligated by LIG3. 


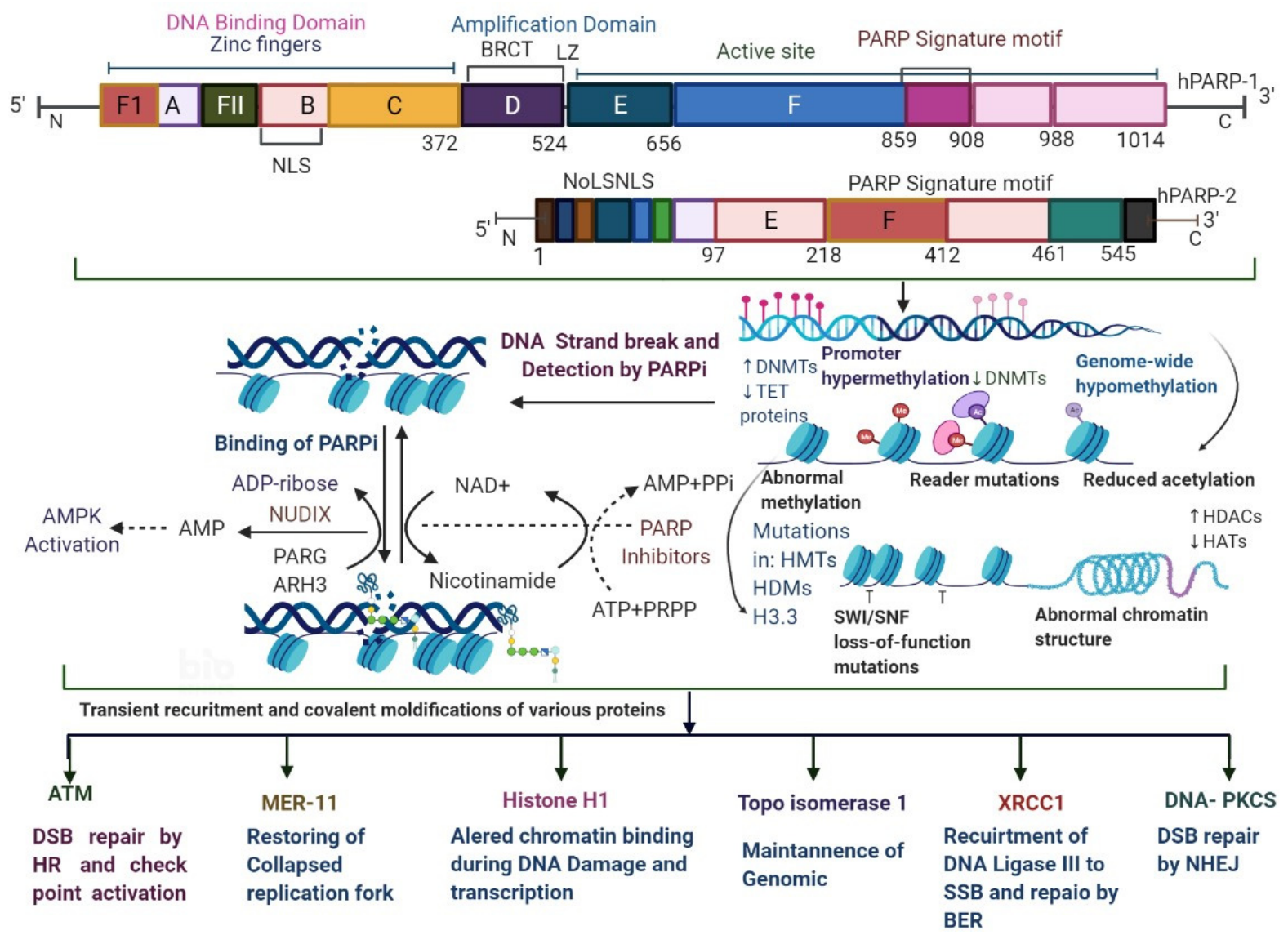

Figure 4. The biochemical functions of PARP1 in DNA damage repair. The domains of PARP1 are shown; PARP1 has a DBD, which contains ZF13 (zinc finger motifs) and NLS (nuclear localization signals); its central domain contains the interaction motifs BRCA1 C-terminal domain and a carboxy-terminal catalytic domain, which contains a signature of PARP and CD. The $\mathrm{CD}$ contains the active site and binds to NAD+, as well as to the Trp-Gly-Arg (WGR) domain. PARP1 detects DNA damage through its DBD, and it is activated by synthesizing PAR (poly(ADP-ribose)) chains-mainly on itself, but also on some of its target proteins. NAD+ is used as a substrate for PAR formation and is replenished in cells from nicotinamide using ATP. PAR chains are rapidly catabolized by PARG (PAR glycohydrolase), ARH3 (ADP-ribosylhydrolase 3), and OARD1 (O-acyl-ADP-ribose deacetylase 1). PARG cleaves the glycosidic ribose-ribose bonds of PAR. Histone deacetylase genes (HDACs) increase the expression of genes through transcription activation By deacetylating the histone tails, the DNA becomes more tightly wrapped around the histone cores, making it harder for transcription factors to bind to the DNA, which could be attributed to decrease in histone acetyltransferase (HAT). However, cleavage of the terminal ADP-ribose moiety requires OARD1, and results in the release of mono(ADP-ribose). Poly(ADP) ribosylation (PARylation) of PARP1 and other target proteins, both covalently and non-covalently, results in the recruitment of multiple proteins that have roles in different aspects of DNA damage repair.

The role of PARP1 in DNA repair mechanisms was assumed in 1975, after which, more effective PARP inhibitors were established in 1990, which were found to be more effective in DNA repair mechanisms, as shown in Figures 2-4 [12-17]; these are triggered by topoisomerase 1 toxicity and prevent re-ligation of DNA at SSBs [20]. PARP1 distinguishes the SSB via its DNA-binding domain with motifs of three zinc fingers, which cause a change in their conformational structure and trigger PARP1 to cleave NAD+, as shown in Figure 4 [21-24]. The ADP-ribose moiety covalently attaches to either PARP1 or other nuclear proteins, such as histones; other ADP-ribose groups are then added to it to produce long and sometimes branching PAR chains [22,23]. SSBs are identified and repair DNA damage by DSB (DNA double-strand break) repair pathways via the homologous recombination (HR) and non-homologous end-joining (NHEJ) pathways. Damaged DNA at broken chromatin terminals is repaired by alt-NHEJ (alternative end-joining) and MMEJ 
(microhomology-mediated end-joining) [23-26]. HR acts as a conventional repair mechanism with reliability in the $\mathrm{S}$ and $\mathrm{G} 2$ phases of the cell cycle $[27,28]$. BRCA1 plays an important role in cell cycle regulation and SSB; $B R C A 2$ mediates the important recombination enzyme RAD51 and regulates DNA repair mechanisms, as shown in Figure 3 [29,30]. $B R C A 1$ mutations are linked to TNBC and BRCA2 mutations are associated with ER/PRpositive tumors $[3,16]$. DNA damage repair is associated with the HRR pathway and accomplished by MRE11, RAD50, and Exo1 (MRN complex). PARP trapping occurs via the NHEJ pathway at the replication fork via enzymes such as DNA-PK, XRCC4, and Ku70/80, which are employed to undertake the DNA repair process [31-33]. Another pathway of MMEJ or NHEJ leads to chromosomal and genomic instability and causes tumor cell death or somatic mutations, as shown in Figure 3 [31]. Treating TNBC by PARPi is an important mechanism due to HR deficiency and accumulated mutations. In response to DNA damage, PARylation occurs [31,34], and RNAi-mediated depletion of PARP1 encourages the destruction of $B R C A 1 / 2$-lacking tumor cells [16]. PARPi treatment displays antitumor effects in patients with $B R C A 1 / 2$ mutations $[3,16]$. Approximately $10-20 \%$ mutations have been observed in TNBC patients [2,3]. PARPi have shown effective clinical outcomes (Tables 1 and 2) [34-37]. The FDA (Food and Drug Administration) has approved olaparib and talazoparib for the treatment of TNBC patients with $B R C A 1 / 2$ mutations (Tables 1-3) [16,35-39]. Researchers from the field have reported that HR mechanisms also repair genetic mutations other than those in BRCA genes, such as CDK12, RAD51B, RAD51C, RAD51D, CHEK1, CHEK2, FANCA, FANCC, FANCD2, FRANCE, FANCF, ATM, PALB2, NBS1, ATR, BAP1, WRN, MRE11A, and BLM [3,31-40]. Similar treatment responses in cancers with $B R C A$ ness and $B R C A 1 / 2$-mutated tumors have been observed $[3,16]$. PARPi limits the DNA-damage response induced by chemotherapy and radiotherapy (Tables 1-3) [40].

Table 1. List of PARP inhibitors.

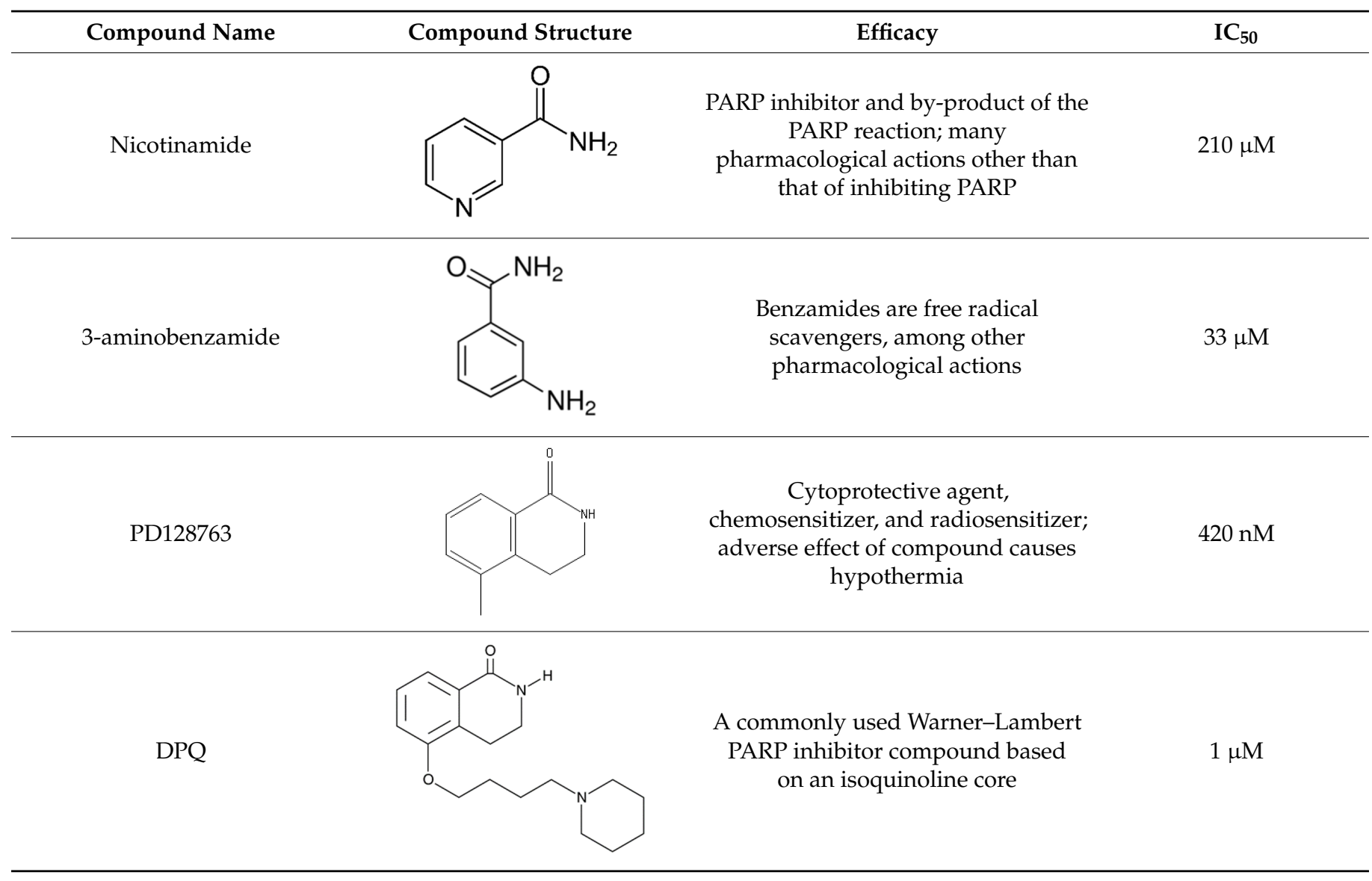


Table 1. Cont.

Compound Name

Olaparib

(Lynparza)

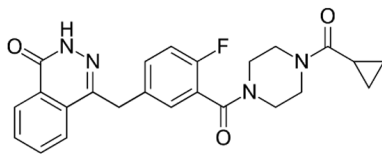

Use in a BRCA1-positive patient with metastatic triple-negative breast cancer, without the initial use of platinum-based chemotherapy, showed significant rapid near-resolution of large liver metastasis while patient experienced gout-like symptoms
Niraparib (Zejula)

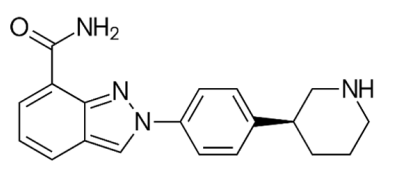

Niraparib in combination with pembrolizumab in patients with triple-negative breast cancer
$1 \mathrm{nM}$

$4 \mathrm{nM}$

Ferm line BRCA-mutant, HER2-negative locally advanced or metastatic breast cancer

$0.6 \mathrm{nM}$
Talazoparib
(Talzenna)<smiles>Cn1ncnc1[C@H]1c2n[nH]c(=O)c3cc(F)cc(c23)N[C@H]1c1ccc(F)cc1</smiles>

Received orphan drug status for lung cancer

Veliparib (ABT-888)

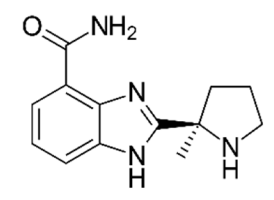

Potent enhancer of radiation sensitivity and enhances radiation-induced cell killing by interfering with DNA repair mechanisms, resulting in necrotic cell death
105 nM 
Table 1. Cont.

Compound Name
$\begin{aligned} & \text { Pamiparib } \\ & \text { (BGB-290) }\end{aligned}$

Table 2. Efficacy of PARP inhibitors.

\begin{tabular}{|c|c|c|c|c|c|c|c|}
\hline $\begin{array}{l}\text { Name of the } \\
\text { Molecules }\end{array}$ & $\mathrm{T}_{\max }(\mathrm{h})$ & $t(h)$ & AUC (lgh/ mL) & $C_{\max }(\lg / m L)$ & $\mathrm{CL} / \mathrm{F}(\mathrm{L} / \mathrm{h})$ & $\mathbf{V}_{\mathbf{z}} / \mathbf{F}$ & References \\
\hline $\begin{array}{c}\text { Olaparib capsule } \\
\text { formulation } 300 \mathrm{mg}\end{array}$ & $\begin{array}{c}1.49 \\
(0.57-3.05)\end{array}$ & $13.02(8.23)$ & $55.20(67.4)$ & $8.05(24.3)$ & $6.36(3.47)$ & $112.1(59.84)$ & {$[30]$} \\
\hline $\begin{array}{l}\text { Olaparib tablet } \\
\text { formulation } 300 \mathrm{mg} \\
\text { single dose (fasted) }\end{array}$ & $\begin{array}{c}1.50 \\
(0.50-5.85)\end{array}$ & $\begin{array}{c}12.2 \\
(5.31)\end{array}$ & $\begin{array}{l}43.6(54.3) \\
{\left[\mathrm{AUC}_{\mathrm{t}}\right]} \\
43.0(55.2) \\
{[\mathrm{AUC}]}\end{array}$ & $7.00(35.0)$ & $7.95(4.23)$ & $146(142)$ & [32] \\
\hline $\begin{array}{l}\text { Olaparib tablet } \\
\text { formulation } 300 \mathrm{mg} \\
\text { single dose (fed) }\end{array}$ & $\begin{array}{c}4.00 \\
(1.00-12.0)\end{array}$ & $\begin{array}{c}12.2 \\
(5.31)\end{array}$ & $\begin{array}{l}46.0(56.6) \\
{\left[\mathrm{AUC}_{\mathrm{t}}\right]} \\
45.4(57.1) \\
{[\mathrm{AUC}]}\end{array}$ & $5.48(40.5)$ & 7.55 (3.99) & 127 (107) & {$[32]$} \\
\hline $\begin{array}{c}\text { Veliparib } \\
\text { monotherapy } 40 \mathrm{mg} \\
(10 \mathrm{mg}, \text { fasting })\end{array}$ & $1.2 \pm 0.8$ & $5.9 \pm 1.3$ & $\begin{array}{c}2.23 \pm 0.82 \\
{\left[\mathrm{AUC}_{\mathrm{t}}\right]} \\
2.43 \pm 1.07 \\
{[\mathrm{AUC}]}\end{array}$ & $0.36 \pm 0.13$ & $19.0 \pm 7.36$ & NA & \\
\hline $\begin{array}{c}\text { Veliparib } \\
\text { monotherapy } 40 \mathrm{mg} \\
(10 \mathrm{mg}, \mathrm{fed})\end{array}$ & $1.2 \pm 0.7$ & $5.8 \pm 1.2$ & $\begin{array}{c}2.45 \pm 0.93 \\
{\left[\mathrm{AUC}_{\mathrm{t}}\right]} \\
2.65 \pm 1.17 \\
{\left[\mathrm{AUC}_{\mathrm{t}}\right]}\end{array}$ & $0.37 \pm 0.12$ & $17.3 \pm 6.41$ & NA & {$[34,40]$} \\
\hline $\begin{array}{c}\text { Veliparib } \\
\text { monotherapy } 40 \mathrm{mg} \\
(40 \mathrm{mg}, \text { fasting })\end{array}$ & $1.3 \pm 0.9$ & $5.8 \pm 1.3$ & $\begin{array}{l}2.24 \pm 0.98 \\
{\left[\mathrm{AUC}_{\mathrm{t}}\right]} \\
2.45 \pm 1.24 \\
{\left[\mathrm{AUC}_{\mathrm{t}}\right]}\end{array}$ & $0.34 \pm 0.12$ & $19.5 \pm 7.66$ & NA & \\
\hline $\begin{array}{c}\text { Veliparib } \\
\text { monotherapy } 40 \mathrm{mg} \\
(40 \mathrm{mg}, \mathrm{fed})\end{array}$ & $2.5 \pm 1.1$ & $5.8 \pm 1.4$ & $\begin{array}{l}2.14 \pm 0.80 \\
{\left[\mathrm{AUC}_{\mathrm{t}}\right]} \\
2.35 \pm 1.06 \\
{\left[\mathrm{AUC}_{\mathrm{t}}\right]}\end{array}$ & $0.28 \pm 0.09$ & $19.7 \pm 7.51$ & NA & \\
\hline
\end{tabular}


Table 2. Cont.

\begin{tabular}{|c|c|c|c|c|c|c|c|}
\hline $\begin{array}{l}\text { Name of the } \\
\text { Molecules }\end{array}$ & $\mathrm{T}_{\max }(\mathrm{h})$ & $t(h)$ & AUC $(\operatorname{lgh} / \mathrm{mL})$ & $C_{\max }(\lg / m L)$ & $\mathrm{CL} / \mathrm{F}(\mathrm{L} / \mathrm{h})$ & $\mathbf{V}_{\mathbf{z}} / \mathbf{F}$ & References \\
\hline $\begin{array}{c}\text { Veliparib metabolite } \\
\text { M8 }\end{array}$ & $2.4(3.5-9.8)$ & - & $\begin{array}{c}0.3-1.9 \\
{\left[\mathrm{AUC}_{\text {int }}\right]}\end{array}$ & $\begin{array}{c}0.011 \\
(0.007-0.014) \\
\end{array}$ & NA & NA & {$[34,40]$} \\
\hline $\begin{array}{l}\text { Niraparib } 300 \\
\text { mg/day }\end{array}$ & $3.1(2.0-6.1)$ & a & $\begin{array}{c}14.117 \\
(\mathrm{AUC} 24) \mathrm{b}\end{array}$ & 1.921 & NA & NA & [12] \\
\hline $\begin{array}{c}\text { Niraparib } \\
\text { metabolite: } \\
\text { unlabeled M1 } \\
\text { plasma }\end{array}$ & 9.02 & 78.4 & $41.2\left(\mathrm{AUC}_{\mathrm{t}}\right)$ & 476 & NA & NA & [15] \\
\hline
\end{tabular}

Table 3. Clinical Trials of PARP Inhibitors in TNBC.

\begin{tabular}{|c|c|c|c|c|c|}
\hline Name of Drug & Types of Inhibitors & Prior Treatment & Type of Population & Status & $\begin{array}{l}\text { ClinicalTrials.gov } \\
\text { Identifier }\end{array}$ \\
\hline $\begin{array}{c}\text { AZD1775 } \\
\text { in patent with TNBC } \\
\text { LYNPARZATM }\end{array}$ & $\begin{array}{c}\text { PARP } \\
\text { Inhibitor, } \\
\text { patent with TNBC }\end{array}$ & $\begin{array}{c}\text { Olaparib in } \\
\text { combination with } \\
\text { AZD6738 mutated } \\
\text { (ATM) }\end{array}$ & $\begin{array}{c}\text { Inhibitor of } \\
\text { Ataxia-Telangiectasia } \\
\text { and WEE1 inhibitor }\end{array}$ & Phase II & NCT03330847 \\
\hline $\begin{array}{c}\text { AZD1775 } \\
\text { in patent with TNBC } \\
\text { LYNPARZATM }\end{array}$ & $\begin{array}{c}\text { PARP } \\
\text { Inhibitor, } \\
\text { patent with TNBC }\end{array}$ & $\begin{array}{c}\text { Olaparib with } \\
\text { radiation therapy, } \\
\text { after } \\
\text { chemotherapy }\end{array}$ & $\begin{array}{c}\text { Inhibitor of } \\
\text { ataxia-telangiectasia }\end{array}$ & Phase I & NCT03109080 \\
\hline $\begin{array}{c}\text { AZD1775, } \\
\text { LYNPARZATM }\end{array}$ & Patent with TNBC & $\begin{array}{l}\text { Olaparib with } \\
\text { atezolizumab }\end{array}$ & $\begin{array}{c}\text { Inhibitor of } \\
P D-L 1\end{array}$ & Phase II & NCT02849496 \\
\hline $\begin{array}{c}\text { AZD1775, } \\
\text { LYNPARZATM }\end{array}$ & Patent with TNBC & $\begin{array}{l}\text { Oolaparib with } \\
\text { paclitaxel and } \\
\text { carboplatin }\end{array}$ & $\begin{array}{c}\text { Inhibitor of } \\
\text { germline } B R C A \\
\text { mutated }\end{array}$ & Phase II/III & $\begin{array}{l}\text { NCT03150576, } \\
\text { NCT02789332 }\end{array}$ \\
\hline $\begin{array}{c}\text { AZD1775, } \\
\text { LYNPARZATM }\end{array}$ & Patent with TNBC & $\begin{array}{l}\text { Olaparib with } \\
\text { AZD2171 orally }\end{array}$ & $\begin{array}{l}\text { Inhibitor of } V E G F R \\
\text { tyrosine kinase }\end{array}$ & Phase I/II & NCT01116648 \\
\hline $\begin{array}{c}\text { AZD1775, } \\
\text { LYNPARZATM }\end{array}$ & Patent with TNBC & $\begin{array}{l}\text { Olaparib with PI3K } \\
\text { inhibitor, BKM120 }\end{array}$ & Inhibitor of BKM120 & Phase I & NCT01623349 \\
\hline $\begin{array}{c}\text { AZD1775, } \\
\text { LYNPARZATM }\end{array}$ & Patent with TNBC & $\begin{array}{l}\text { Olaparib with } \\
\text { onalespib }\end{array}$ & $\begin{array}{l}\text { Inhibitor of heat } \\
\text { shock protein } 90\end{array}$ & Phase I & NCT02898207 \\
\hline $\begin{array}{c}\text { AZD1775, } \\
\text { LYNPARZATM }\end{array}$ & Patent with TNBC & $\begin{array}{l}\text { Olaparib with } \\
\text { AZD2014 }\end{array}$ & $\begin{array}{c}\text { mTORC1/2 or } \\
\text { Oral AKT inhibitor }\end{array}$ & Phase I/II & NCT02208375 \\
\hline $\begin{array}{c}\text { PARP1/2 inhibitor } \\
\text { Veliparib }\end{array}$ & Patent with TNBC & $\begin{array}{c}\text { Veliparib in } \\
\text { combination } \\
\text { with } \\
\text { cyclophosphamide }\end{array}$ & $\begin{array}{c}\text { Inhibitor of EGFR, } \\
H E R 2, B R C A \text {, and } \\
\text { tyrosine } \\
\text { kinase }\end{array}$ & $\begin{array}{c}\text { Phase II and failed in } \\
\text { phase III trials }\end{array}$ & NCT01306032 \\
\hline $\begin{array}{c}\text { PARP1/2 inhibitor } \\
\text { Veliparib }\end{array}$ & $\begin{array}{c}\text { Inhibitor of } \\
\text { tyrosine } \\
\text { kinase, } H E R 2 \text {, and } \\
B R C A\end{array}$ & $\begin{array}{l}\text { Veliparib in } \\
\text { combination } \\
\text { with carboplatin }\end{array}$ & Patients with TNBC & $\begin{array}{l}\text { Completed phase I } \\
\text { study }\end{array}$ & NCT01251874 \\
\hline $\begin{array}{c}\text { PARP1/2 inhibitor } \\
\text { Veliparib }\end{array}$ & $\begin{array}{l}\text { Inhibitor of } E G F R \text {, } \\
B R C A \text {, and tyrosine } \\
\text { kinase }\end{array}$ & $\begin{array}{l}\text { Veliparib with } \\
\text { vinorelbine }\end{array}$ & Patients with TNBC & Completed phase I & NCT01281150 \\
\hline $\begin{array}{c}\text { PARP1/2 inhibitor } \\
\text { Veliparib }\end{array}$ & $\begin{array}{l}\text { Inhibitor of EGFR, } \\
H E R 2, B R C A \text {, and } \\
\text { tyrosine } \\
\text { kinase }\end{array}$ & $\begin{array}{l}\text { Veliparib with } \\
\text { cisplatin }\end{array}$ & Patients with TNBC & Completed phase I & NCT01104259 \\
\hline $\begin{array}{c}\text { PARP1/2 inhibitor } \\
\text { Veliparib }\end{array}$ & $\begin{array}{c}\text { Inhibitor of EGFR, } \\
H E R 2, B R C A \text {, and } \\
\text { tyrosine } \\
\text { kinase }\end{array}$ & $\begin{array}{l}\text { Veliparib with } \\
\text { pegylation }\end{array}$ & Patients with TNBC & Completed phase I & NCT01145430 \\
\hline
\end{tabular}


Table 3. Cont

\begin{tabular}{|c|c|c|c|c|c|}
\hline Name of Drug & Types of Inhibitors & Prior Treatment & Type of Population & Status & $\begin{array}{l}\text { ClinicalTrials.gov } \\
\text { Identifier }\end{array}$ \\
\hline $\begin{array}{l}\text { PARP1/2 inhibitor } \\
\text { Veliparib }\end{array}$ & $\begin{array}{c}\text { Inhibitor of EGFR, } H E R 2, \\
\text { BRCA, and } \\
\text { tyrosine } \\
\text { kinase }\end{array}$ & $\begin{array}{l}\text { Veliparib with } \\
\text { pegylation }\end{array}$ & Patients with TNBC & Completed phase I & NCT01145430 \\
\hline $\begin{array}{c}\text { PARP1/2 inhibitor } \\
\text { Veliparib }\end{array}$ & $\begin{array}{c}\text { Inhibitor of EGFR, } H E R 2, \\
\text { BRCA, and } \\
\text { tyrosine } \\
\text { kinase }\end{array}$ & $\begin{array}{l}\text { Veliparib with } \\
\text { lapatinib }\end{array}$ & Patients with TNBC & Phase I & NCT02158507 \\
\hline $\begin{array}{l}\text { PARP1/2 inhibitor } \\
\text { Veliparib }\end{array}$ & $\begin{array}{c}\text { Inhibitor of } E G F R, H E R 2, \\
B R C A \text {, and } \\
\text { tyrosine } \\
\text { kinase }\end{array}$ & $\begin{array}{c}\text { Veliparib in } \\
\text { combination with } \\
\text { irinotecan } \mathrm{HCl}\end{array}$ & Patients with TNBC & Phase I I & NCT00576654 \\
\hline $\begin{array}{l}\text { PARP1/2 inhibitor } \\
\text { Veliparib }\end{array}$ & $\begin{array}{c}\text { Inhibitor of EGFR, } H E R 2, \\
\text { BRCA, and } \\
\text { tyrosine } \\
\text { kinase }\end{array}$ & $\begin{array}{l}\text { Veliparib with } \\
\text { cisplatin }\end{array}$ & Patients with TNBC & Phase II & NCT02595905 \\
\hline $\begin{array}{l}\text { AZD2281 and } \\
\text { Ku-0059436 } \\
\text { PARP1/2 inhibitor } \\
\text { (Selective) }\end{array}$ & $\begin{array}{c}\text { PARP inhibitor; } B R C A \\
\text { Mutated }\end{array}$ & $\begin{array}{l}\text { Olaparib alone, or in } \\
\text { combination with } \\
\text { durvalumab } \\
\text { MEDI4736 against } \\
\text { PD-L1 }\end{array}$ & $\begin{array}{l}\text { HER2-negative } \\
\text { treated mTNBC }\end{array}$ & Phase-II & $\begin{array}{l}\text { NCT00679783 } \\
\text { NCT03544125 } \\
\text { NCT02484404 } \\
\text { NCT03167619 } \\
\text { NCT02681562 } \\
\text { NCT02484404 }\end{array}$ \\
\hline $\begin{array}{l}\text { PARP1/2 inhibitor } \\
\text { Veliparib }\end{array}$ & $\begin{array}{c}\text { Inhibitor of EGFR, } H E R 2, \\
\text { BRCA, and } \\
\text { tyrosine } \\
\text { kinase }\end{array}$ & $\begin{array}{l}\text { Veliparib plus } \\
\text { carboplatin }\end{array}$ & Patients with TNBC & Phase III & NCT02032277 \\
\hline $\begin{array}{l}\text { Iniparib BSI-201 } \\
\text { and SAR240550 }\end{array}$ & $\begin{array}{l}\text { Competitive PARP } \\
\text { inhibitor; ability to form } \\
\text { adducts with many } \\
\text { cysteine-containing } \\
\text { proteins }\end{array}$ & $\begin{array}{l}\text { Combination with } \\
\text { gemcitabine and } \\
\text { carboplatin }\end{array}$ & Patients with TNBC & Phase II & $\begin{array}{l}\text { NCT00813956 } \\
\text { NCT01045304 } \\
\text { NCT01130259 }\end{array}$ \\
\hline $\begin{array}{l}\text { Iniparib BSI-201 } \\
\text { and SAR240550 }\end{array}$ & $\begin{array}{l}\text { Competitive PARP } \\
\text { inhibitor; ability to form } \\
\text { adducts with many } \\
\text { cysteine-containing } \\
\text { proteins }\end{array}$ & $\begin{array}{l}\text { Combination of } \\
\text { iniparib } \\
\text { with paclitaxel for } \\
\text { TNBC compared } \\
\text { to paclitaxel alone }\end{array}$ & Patients with TNBC & Competed phase II & NCT01204125 \\
\hline $\begin{array}{l}\text { Iniparib BSI-201 } \\
\text { and SAR240550 }\end{array}$ & $\begin{array}{l}\text { Competitive PARP } \\
\text { inhibitor; ability to form } \\
\text { adducts with many } \\
\text { cysteine-containing } \\
\text { proteins }\end{array}$ & $\begin{array}{l}\text { Iniparib with } \\
\text { irinotecan }\end{array}$ & Patients with TNBC & Phase II trial & NCT01173497 \\
\hline Niraparib & $\begin{array}{l}\geq 1 \text { anti-HER2 treatment; } \\
\text { PARP inhibitor }\end{array}$ & $\begin{array}{l}\text { Niraparib } \\
\text { plus } \\
\text { trastuzumab IV }\end{array}$ & $\begin{array}{c}\text { Metastatic } H E R 2+ \\
\text { breast } \\
\text { cancer }\end{array}$ & $\begin{array}{l}\text { Phase } \mathrm{Ib} / \mathrm{II} \\
\text { (recruiting) }\end{array}$ & NCT03368729 \\
\hline Niraparib & PARP inhibitor & $\begin{array}{l}\text { One anthracycline } \\
\text { and/or } \\
\text { taxane in the (neo-) } \\
\text { adjuvant } \\
\text { or Niraparib }\end{array}$ & $\begin{array}{c}\text { Advanced/metastatic } \\
\text { BRCA1- } \\
\text { like }\end{array}$ & $\begin{array}{l}\text { Phase-II, Active, not } \\
\text { recruiting }\end{array}$ & NCT02826512 \\
\hline Niraparib & PARP inhibitor & $\begin{array}{l}\geq 1 \text { line of therapy } \\
\text { Niraparib } \\
\text { plus everolimus }\end{array}$ & Patients with TNBC & Phase I Recruiting & NCT03154281 \\
\hline Niraparib & $\begin{array}{c}\text { Germline } \\
\text { BRCA mutation-positive } \\
\text { (PARP inhibitors) }\end{array}$ & $\begin{array}{l}\leq 2 \text { prior cytotoxic } \\
\text { regimens and } \\
\text { Niraparib } \\
\text { versus } \\
\text { physician's choice }\end{array}$ & $\begin{array}{l}\text { Advanced or } \\
\text { metastatic } \\
\text { breast cancer }\end{array}$ & $\begin{array}{l}\text { Phase III Active, } \\
\text { not yet } \\
\text { recruiting }\end{array}$ & $\begin{array}{l}\text { NCT01905592 } \\
\text { (BRAVO) }\end{array}$ \\
\hline
\end{tabular}


Table 3. Cont.

\begin{tabular}{|c|c|c|c|c|c|}
\hline $\begin{array}{l}\text { Name of } \\
\text { Drug }\end{array}$ & Types of Inhibitors & Prior Treatment & Type of Population & Status & $\begin{array}{l}\text { ClinicalTrials.gov } \\
\text { Identifier }\end{array}$ \\
\hline Niraparib & $\begin{array}{c}\text { Metastatic } \\
\text { TNBC inhibitors } \\
\text { (PARP inhibitors) }\end{array}$ & $\begin{array}{c}\leq 2 \text { lines of cytotoxic } \\
\text { therapy, } \\
\text { Niraparib } \\
\text { plus } \\
\text { pembrolizumab }\end{array}$ & $\begin{array}{l}\text { Advanced or } \\
\text { metastatic } \\
\text { TNBC }\end{array}$ & $\begin{array}{c}\text { Phase I/II Active, not } \\
\text { yet } \\
\text { recruiting }\end{array}$ & $\begin{array}{c}\text { NCT02657889 } \\
\text { (KEYNOTE-162) }\end{array}$ \\
\hline veliparib & $\begin{array}{l}\text { Metastatic } \\
\text { TNBC inhibitors } \\
\text { (PARP inhibitors) }\end{array}$ & $\begin{array}{c}\leq 2 \text { lines of cytotoxic } \\
\text { Chemotherapy, } \\
\text { Carboplatin, and paclitaxel } \\
\text { with or without veliparib }\end{array}$ & $\begin{array}{l}\text { Locally advanced } \\
\text { unresectable } B R C A \\
\text { associated }\end{array}$ & Phase III Recruiting & NCT02163694 \\
\hline veliparib & $\begin{array}{c}\text { Metastatic } \\
\text { TNBC inhibitors } \\
\text { (PARP inhibitors) }\end{array}$ & $\begin{array}{l}\text { Veliparib with } \\
\text { temozolomide } \\
\text { versus veliparib with } \\
\text { carboplatin and paclitaxel } \\
\text { versus placebo with } \\
\text { carboplatin and paclitaxel } \\
\leq 2 \text { lines of cytotoxic } \\
\text { chemotherapy }\end{array}$ & $\begin{array}{l}\text { Metastatic } \\
\text { TNBC }\end{array}$ & $\begin{array}{c}\text { Randomized } \\
\text { phase II, Ongoing }\end{array}$ & NCT01506609 \\
\hline veliparib & $\begin{array}{c}\text { Metastatic } \\
\text { TNBC inhibitors } \\
\text { (PARP inhibitors) }\end{array}$ & $\begin{array}{c}\text { Veliparib versus } \\
\text { atezolizumab versus } \\
\text { veliparib plus atezolizumab }\end{array}$ & Stage III-IV TNBC & $\begin{array}{c}\text { Randomized } \\
\text { phase II Ongoing }\end{array}$ & NCT02849496 \\
\hline veliparib & $\begin{array}{c}\text { Metastatic } \\
\text { TNBC inhibitors } \\
\text { PARP inhibitors) }\end{array}$ & $\begin{array}{l}\text { Cisplatin and placebo } \\
\text { versus cisplatin and } \\
\text { veliparib } \\
\leq 1 \text { line of cytotoxic } \\
\text { chemotherapy for } \\
\text { metastatic disease }\end{array}$ & $\begin{array}{c}\text { Metastatic TNBC } \\
\text { and/or } \\
B R C A \\
\text { mutation-associated } \\
\text { breast cancer }\end{array}$ & $\begin{array}{l}\text { Phase II Active, not } \\
\text { recruiting }\end{array}$ & NCT02595905 \\
\hline veliparib & $\begin{array}{c}\text { Metastatic } \\
\text { TNBC inhibitors } \\
\text { PARP inhibitors) }\end{array}$ & $\begin{array}{l}\text { Temozolomide and } \\
\text { veliparib } \\
\geq 1 \text { chemotherapy } \\
\text { regimen }\end{array}$ & $\begin{array}{c}\text { Metastatic TNBC } \\
\text { and/or } \\
B R C A \\
\text { mutation-associated } \\
\text { breast cancer }\end{array}$ & $\begin{array}{l}\text { Phase II, Active, not } \\
\text { recruiting }\end{array}$ & NCT01009788 \\
\hline Talazoparib & Neoadjuvant therapy & None & $\begin{array}{c}\text { Primary breast cancer } \\
\geq 1 \\
\text { cm with a deleterious } \\
\text { BRCA mutation }\end{array}$ & $\begin{array}{l}\text { Phase II, Active, not } \\
\text { recruiting }\end{array}$ & NCT02282345 \\
\hline Talazoparib & $\begin{array}{l}\text { Advanced TNBC and HR } \\
\text { deficiency and advanced } \\
\text { HER2-negative breast } \\
\text { cancer or other solid } \\
\text { tumors with a } \\
\text { mutation in HR pathway } \\
\text { genes }\end{array}$ & $\geq 1$ line of therapy & Talazoparib & Phase II, Recruiting & NCT02401347 \\
\hline Talazoparib & $\begin{array}{c}\text { Metastatic } \\
\text { TNBC inhibitors } \\
\text { PARP inhibitors }\end{array}$ & $\begin{array}{c}\text { Platinum-containing } \\
\text { regimen } \\
\text { with disease } \\
\text { progression }>8 \\
\text { weeks }\end{array}$ & $\begin{array}{c}\text { Metastatic breast } \\
\text { cancer } \\
\text { with } B R C A \text { mutation }\end{array}$ & $\begin{array}{l}\text { Phase II Terminated } \\
\text { (Primary Analysis } \\
\text { and study completed } \\
\text { Not stopped }\end{array}$ & $\begin{array}{l}\text { NCT02034916 } \\
\text { (ABRAZO) }\end{array}$ \\
\hline Talazoparib & $\begin{array}{l}\text { Metastatic } \\
\text { TNBC inhibitors } \\
\text { PARP inhibitors }\end{array}$ & $\begin{array}{c}\leq 3 \text { chemotherapy-inclusive } \\
\text { regimens Talazoparib } \\
\text { versus physician's } \\
\text { choice }\end{array}$ & $\begin{array}{c}\text { Locally advanced } \\
\text { and/or } \\
\text { metastatic breast } \\
\text { cancer } \\
\text { with germline } B R C A \\
\text { mutations }\end{array}$ & Phase III Completed & $\begin{array}{l}\text { NCT01945775 } \\
\text { (EMBRACA) }\end{array}$ \\
\hline Rucaparib & $\begin{array}{c}\text { Metastatic } \\
\text { TNBC inhibitors } \\
\text { PARP inhibitors }\end{array}$ & $\begin{array}{l}\leq 5 \text { prior chemotherapy } \\
\text { Rucaparib } \\
\text { regimens in the last } 5 \text { years }\end{array}$ & $\begin{array}{l}\text { Patients presenting } \\
\text { with metastatic } \\
\text { breast cancer (MBC) }\end{array}$ & Phase II, Completed & NCT00664781 \\
\hline
\end{tabular}


Table 3. Cont.

\begin{tabular}{|c|c|c|c|c|c|}
\hline Name of Drug & Types of Inhibitors & Prior Treatment & Type of Population & Status & $\begin{array}{c}\text { ClinicalTrials.gov } \\
\text { Identifier }\end{array}$ \\
\hline Rucaparib & $\begin{array}{c}\text { Metastatic } \\
\text { TNBC inhibitors } \\
\text { PARP inhibitors }\end{array}$ & $\begin{array}{l}\geq 1 \text { line of } \\
\text { chemotherapy, } \\
\text { Rucaparib }\end{array}$ & $\begin{array}{l}\text { Patients with a } B R C A \text { ness } \\
\text { genomic signature }\end{array}$ & Phase II Completed & $\begin{array}{l}\text { NCT02505048 } \\
\text { (RUBY) }\end{array}$ \\
\hline Rucaparib & $\begin{array}{l}\text { Stage I-III patients with } \\
\text { TNBC or inhibitors } \\
\text { PARP inhibitors }\end{array}$ & $\begin{array}{l}\text { Neoadjuvant } \\
\text { chemotherapy } \\
\text { Cisplatin with } \\
\text { rucaparib }\end{array}$ & $\begin{array}{c}E R / P R+, H E R 2- \\
\text { negative breast cancer } \\
\text { with known } B R C A 1 / 2 \\
\text { mutations }\end{array}$ & Phase II Completed & NCT01074970 \\
\hline Rucaparib & TNBC inhibitors & $\begin{array}{l}\geq 3 \text { prior } \\
\text { chemotherapy } \\
\text { regimens, Rucaparib }\end{array}$ & $\begin{array}{l}\text { Patients with advanced } \\
\text { solid tumors with } \\
\text { evidence of } \\
\text { germline }\end{array}$ & $\begin{array}{l}\text { Phase I/II Active, not } \\
\text { recruiting }\end{array}$ & NCT01482715 \\
\hline Rucaparib & TNBC inhibitors & $\begin{array}{l}\leq 5 \text { prior } \\
\text { chemotherapy } \\
\text { regimens in the last } 5 \\
\text { years, Rucaparib }\end{array}$ & $\begin{array}{l}\text { Patients with } M B C \\
\text { carriers of a } B R C A 1 / 2\end{array}$ & Phase II Completed & NCT00664781 \\
\hline Rucaparib & TNBC inhibitors & $\begin{array}{l}\geq 1 \text { line of } \\
\text { chemotherapy } \\
\text { Rucaparib }\end{array}$ & $\begin{array}{l}\text { Patients with a } B R C A \text { ness } \\
\text { genomic signature }\end{array}$ & Phase II Completed & $\begin{array}{l}\text { NCT02505048 } \\
\quad(\text { RUBY) }\end{array}$ \\
\hline Rucaparib & TNBC inhibitors & $\begin{array}{l}\text { Neoadjuvant } \\
\text { chemotherapy } \\
\text { Cisplatin with } \\
\text { rucaparib }\end{array}$ & $\begin{array}{l}\text { Advanced solid } \\
\text { tumors with evidence of } \\
\text { germline or somatic } \\
B R C A \text { mutation }\end{array}$ & Completed & NCT01074970 \\
\hline Rucaparib & TNBC inhibitors & $\begin{array}{l}\geq 3 \text { prior } \\
\text { chemotherapy } \\
\text { regimens }\end{array}$ & $\begin{array}{l}\text { Advanced solid } \\
\text { tumors with evidence of } \\
\text { germline or somatic } \\
B R C A \text { mutation }\end{array}$ & $\begin{array}{l}\text { Phase I/II Active, not } \\
\text { recruiting }\end{array}$ & NCT01482715 \\
\hline
\end{tabular}

\subsection{PARP Inhibition and the PI3K/AKT/mTOR Pathway}

TNBCs exhibit aberrant initiation of the PI3K pathway via various mechanisms; the $\mathrm{PI} 3 \mathrm{~K} / \mathrm{AKT} / \mathrm{mTOR}$ pathway has been investigated for therapeutic strategies in patients with TNBC [3]. PI3K is also actively involved in the DSB repair mechanism via use of the HR complex [41]. Researchers from the field have investigated the inhibition of PI3K, which causes DNA damage, downregulates BRCA 1 and 2, increases poly-ADP ribosylation and, finally, activates PARP inhibition. PI3K and PARP inhibitors have been investigated in a mouse model for BRCA1-related tumors, and provide synergistic effects in their treatment [42]. In addition, PI3K-mTOR is inhibited by GDC-0980, and was tested in combination with veliparib and carboplatin in a TNBC model. Furthermore, a combination of veliparib and carboplatin has been shown to be effective against xenograft tumors [40]. The mTOR signaling pathway is an important target strategy for TNBC [42]—it causes downregulation of the PI3K pathway and also suppresses the regulation of TNBC cell lines [3,42]. A combination of PARP inhibitors and mTOR inhibitors has shown significant activity in TNBC cell lines [43,44].

\subsection{PARP Inhibitors Combined with CDK1 Inhibitors}

$C D K 1$ is required for HR and check-point activation and is mediated by BRCA1 [43]. CDK1 inhibition modulates the repair of DNA by HR [43,44]; PARP and CDK1 inhibition in $B R C A$ reduces the formation of tumors in xenograft models. $C D K 1$ and PARP inhibition has been shown to be a promising emerging approach for BRCA tumor treatment $[45,46]$. CDK1 activity is impaired by $B R C A 1$, working via the HR repair mechanism [46]. Researchers from the field have investigated the combined effects of $C D K 1$ inhibition using RO3306 and olaparib in BRCA tumors [29]. 


\subsection{PARP Inhibitors Combined with Histone Deacetylase Inhibitors}

HDI (histone deacetylase inhibitors) stimulate tumor cells to inhibit PARP and enhance antitumor activity against TNBC cells based on their BRCAness [47]. HAD blockade prevents deacetylation of HSP90 (heat shock protein 90) and leads to inhibition of hyperacetylation; as a result, HSP70 cannot interact with CHK1, RAD52, ATR, and $B R C A 1$ [48,49]. HDI and PARP inhibitors are considered epigenetic drugs [47,48]. The combined drugs act synergistically; combinations of HDI and PARP inhibitors have been clinically evaluated for treatment of neoplastic diseases [50]. Cell proliferation inhibition is linked with rising apoptosis levels, leads to DNA damage, and alters the cAMP signaling mechanism [10-15]. The combined effects of SAHA and PJ34 have shown effective results in leukemia cell lines [51]. Combinations of HDI and PARP inhibitors can reduce proliferation and induce apoptosis. Additionally, they are emerging as an effective treatment approach for TNBC $[47,50,51]$.

\subsection{PARP Inhibitors Combined with EGFR Inhibitors}

In TNBC patients, overexpression of EGFR is observed and associated with a basal-like phenotype [3]. EGFR is a transmembrane receptor that stimulates growth factor signaling pathways, such as the HER1 family, and is actively involved in cell cycle regulation, differentiation, proliferation, and survival $[52,53]$. EGFR-targeted therapies are based on tyrosine kinase inhibitors (TKIs), monoclonal antibodies, and combination chemotherapy [53]. EGFR inhibition changes the DNA DSB repair capacity of treated cells; EGFR1 and 2 inhibitor lapatinib encourages a momentary DNA repair discrepancy in human TNBC cells and then enhances the cytotoxicity of the PARP inhibitor veliparib [40]. The targeting of MET, which acts as a regulator for EGFR tyrosine kinase phosphorylation, has shown effective results in patients with TNBC in combination with EGFR inhibition $[40,52,53]$.

\subsection{ATM Downregulation and PARP Inhibition}

Ataxia-telangiectasia mutated (ATM) is a tumor suppressor gene whose stimulation is linked to oxidative stress and which can moderate the cellular response to oxidative stress $[3,54,55]$. ATM-based regulation of pexophagy, proteostasis, mitophagy, and autophagy highlights the need to remain aware that the consequences of ATM expression and signaling pathways are dependent on the specific cellular context. Investigations are urgently needed to determine the molecular mechanisms of the cytosolic functions of ATM that could modify tumor development and therapy [54,55]. Researchers from the field have used genetic modification to suppress ATM expression, using iniparib and olaparib with PARP inhibitors $[29,56]$. After treatment with iniparib and olaparib, different types of responses are produced [56]. Olaparib treatment was more effective than iniparib against TNBC [29]. Transforming growth factor-beta (TGF- $\beta$ ) suppresses ATM in BC cells by stimulating the miR-181 family and targeting the $3^{\prime}$ untranslated regions of ATM transcripts [57]. TGF- $\beta$ activates this PARP inhibitor mechanism, as demonstrated in preclinical in vitro and in vivo TNBC models $[3,41,57]$.

\subsection{PARP Inhibitors Combined with Androgen Receptor (AR) Inhibitors}

AR is expressed in $15 \%-50 \%$ of TNBCs and represents an opportunity for targeted therapy of TNBCs [58]. A combination of AR inhibitors and PARP1 inhibitors could be a promising target for sporadic positive-AR expression and methylation-mediated BRCA1 dysfunction in patients with TNBC [58,59]. The AR antagonist MDV3100 (enzalutamide) has an antitumor potency greater than first-generation AR inhibitors; it suppresses AR nuclear translocation and decreases DNA binding and coactivator recruitment [60]. Researchers from the field have reported effective responses against MDV3100 in AR-positive BT-549 cells and resistant responses in AR-negative MDA-MB-468 and MDA-MB-231 cells [61]; MDV3100 improved the PARP1 inhibitor olaparib-mediated reduction of cell viability in AR-positive and BRCA1-inactivated BT-549 cells in vitro and in vivo. AR antagonism with PARP1 inhibitors can be an effective target in patients with TNBC $[62,63]$. 
Enzalutamide with olaparib inhibited proliferation and suppressed the growth of prostate cancer xenografts in mice [64]. Given that one of the TNBC subtypes (LAR) expresses androgen receptors, the combination of antiandrogens and PARP inhibitors could be an effective treatment for this subset of patients with TNBC $[3,62,64]$.

\section{Clinical Applications of PARP Inhibitors in TNBC}

PARP inhibitors have been shown to have effective clinical outcomes against different types of cancer. There are various clinical trials registered investigating PARPi therapies (Tables 1-3).

\subsection{Olaparib}

Olaparib is a potent oral PARP inhibitor effective against BRCA1 and BRCA2 mutations [29]. A multicentric clinical evaluation of olaparib was carried out using it as a monotherapy for inpatients with germline $B R C A 1 / 2$ mutations $[56,62,63]$. Olaparib was administered to the patient twice a day at a dose of $400 \mathrm{mg}$. The clinical trial was performed with 298 patients, out of which, effective clinical therapy was observed in $12.9 \%$, with adverse effects of vomiting, nausea, and fatigue observed [64-68]. Another study was performed to optimize the drug concentration and determine its maximum dose and minimum dose. In patients with BRCA1 and BRCA2 mutations, an ORR (overall response rate) of 11 (41\%) was observed in 27 patients with a $400 \mathrm{mg}$ dose twice daily. An ORR of $6(22 \%)$ was observed in 27 patients with $100 \mathrm{mg}$ doses twice daily; the ORR was observed to be $7 / 13(54 \%)$ with higher doses and 4/16 (25\%) with lower doses in TNBC patients. In higher dose-tested patients, some adverse effects were observed, such as anemia, vomiting, nausea, and fatigue. Olaparib was approved by the FDA based on the clinical outcomes of the patient [65-68]. A phase 3 clinical trial employed olaparib monotherapy in germline $B R C A$ mutations with $H E R 2$ negativity and, at minimum, previous chemotherapy therapy [67]. A total of 300 patients were selected randomly in a 2:1 ratio into two groups; group one was administered $300 \mathrm{mg}$ olaparib twice daily, and 92 patients in group two were administered vinorelbine or capecitabine and eribulin in 21-day cycles. Out of 300, 49.8\% of the TNBC patients were included in the olaparib group and $49.5 \%$ of the TNBC patients received standard therapy [3,64-66]. Median PFS was significantly longer in the olaparib group than in the standard therapy group (7.0 months vs. 4.2 months; hazard ratio for disease progression or death, $0.58 ; 95 \% \mathrm{CI}, 0.43$ to $0.80 ; p<0.001)$. In the subgroup analysis, the hazard ratio for PFS was 0.43 (95\% CI, 0.29-0.63) for patients with TNBC [3,66-68]. The response rate was $59.9 \%$ in the olaparib group and $28.8 \%$ in the standard therapy group, while the rate of grade 3 or higher adverse events was $36.6 \%$ in the olaparib group and $50.5 \%$ in the standard therapy group; the rate of treatment discontinuation due to toxic effects was $4.9 \%$ and $7.7 \%$, respectively [66-69]. Metabolism of olaparib occurs via oxidation and dehydrogenation and does so progressively via the use of other factors such as sulfate conjugate and glucuronide $[65,66]$. Olaparib is mainly excreted through urine $(44 \%)$ and feces $(42 \%)$ [66].

OlympiAD was a randomized open clinical phase III trial (NCT02000622) assessing the daily administration of $600 \mathrm{mg}$ olaparib tablets. A total of 302 patients who had received two or fewer prior treatments were randomized in a 2:1 ratio to olaparib or chemotherapy. The results showed significantly prolonged PFS with olaparib versus standard therapy (7.0 vs. 4.2 months; hazard ratio (HR), $0.58 ; 95 \%$ CI, $0.43-0.8 ; p<0.001$ ); Response rates were observed to be $59.9 \%$ vs. $28.8 \%$ (olaparib vs. standard group) [64]. Olaparib was the first PARP inhibitor to establish higher efficacy and tolerability than standard chemotherapy in gBRCA-mutated advanced BC [65-68]. According to earlier results, the FDA approved olaparib as the first PARP inhibitor for the treatment of this patient subgroup. However, in the interim analysis, no differences in overall survival (OS) were observed between the two groups [68-70]. The 3-year OS was $40.8 \%$ versus $12.8 \%$ in the two groups, respectively, in patients with TNBC. Currently, research on PARP inhibitors for adjuvant therapy and neoadjuvant therapy, as well as for the prevention of $B C$, is 
ongoing-including the OlympiA (phase III) and GeparSixto studies; in the future, the results of these studies will evaluate adjuvant therapy with olaparib for HER-2-/gBRCAm $B C$ and explore the value of a PARP inhibitor in neoadjuvant therapy, respectively [71-73]. Various remarkable drugs have been approved to benefit patients with TNBC, including the PARP inhibitors olaparib and talazoparib for germline $B R C A$ mutation-associated breast cancer ( $\mathrm{g} B R C A \mathrm{~m}-\mathrm{BC})$ and immunotherapy using the checkpoint inhibitor atezolizumab, in combination with nab-paclitaxel for programmed cell death-ligand 1-positive (PD-L1+) advanced TNBC $[66,73]$.

\subsection{Iniparib (BSI-201)}

Iniparib was the first potent PARP1 inhibitor, effective against cancer cell lines with 40-128 $\mu$ M IC50 values, and is not toxic at $200 \mathrm{mg} / \mathrm{kg}$ in Syrian hamsters [74,75]. The efficacy of iniparib (BSI-201) was established by caspase-3 and TUNEL staining of OVCAR3 tumors; iniparib efficacy was high in combination with topotecan [70-72]. Iniparib used together with a PARP-1 inhibitor has also shown efficacy in DNA repair mechanisms [72]. One clinical trial investigated patients with metastatic TNBC [74,75], in which a total of 123 patients were selected randomly and two groups were made; in each group, patients received $1000 \mathrm{mg} / \mathrm{m}^{2}$ gemcitabine and carboplatin on days 1 and 8 , either with or without $5.6 \mathrm{mg} / \mathrm{kg}$ iniparib on days $1,4,8$, and 11 , over a cycle of 21 days [74,76]. The clinical efficacy of iniparib was increased with carboplatin and gemcitabine, and the ORR was increased from $32 \%$ to $52 \%$. The time duration of the iniparib dose was also increased from a median PFS of 3.6 months to 5.9 months, and the median ORR from 7.7 months to 12.3 months; the hazard ratio for death was observed to be $0.57 ; p=0.01$. ORR and PFS were analyzed further in a phase III clinical trial; the trial did not find successful treatment of patients [76].

\subsection{Niraparib}

Niraparib is a PARP1 and PARP1 inhibitor. Niraparib is indicated as a maintenance treatment for recurrent cancer patients, mainly with HR deficiency (HRD) with positive status [73,77]. HRD has been linked to deleterious $B R C A$ mutations in patients, with disease development occurring more than six months later following platinum-based chemotherapy $[73,77]$. Niraparib was extended for use in the care treatment of adults following first-line platinum-based chemotherapy $[67,73]$.

Patients with solid tumors (BRCA1 or BRCA2 mutation carrier) were enrolled in a phase I clinical trial [76-79]. The currently used therapeutic option was tested along with niraparib in $B R C A$-mutated metastatic breast cancer; patients with germline $B R C A$ mutations were treated with a PARP inhibitor rather than chemotherapy, and the availability of PARP inhibitors increased [76-79]. No safety concerns have been noted by the IDMC (Independent Data Monitoring Committee) concerning niraparib [76-79]. The clinical outcome from the BRAVO (Breast Cancer Risk and Various Outcomes) trial is expected to be supportive of a planned trial of niraparib in combination with an anti-PD-1 antibody in women with metastatic TNBC [76-79].

\subsection{Veliparib (ABT-888)}

Veliparib (ABT-888) is a potent PARP1 and PARP2 inhibitor used as a neoadjuvant. It has good pharmacokinetic properties and has shown effective clinical outcomes [80]. Veliparib is effective in platinum-based therapy in xenograft models $[80,81]$. Significantly, the eradication of solid tumors following neoadjuvant chemotherapy, designated the clinicalpathological response in breast and axillary nodes during surgery, is connected with progression-free survival (PFS) and overall survival rates (OSRs) - with strong correlations in TNBC and HER2-positive disease, raising interest in the neoadjuvant approach $[82,83]$. Veliparib was clinically evaluated in TNBC patients in combination with carboplatin; it was also tested against the NAD+ catalytic enzyme SIRT2, showing inactivity against $>5000 \mathrm{nM}$ of the enzyme. Receptor-binding assays were performed in 74 patients for Veliparib re- 
ceptor profile analysis at a concentration of $10 \mu \mathrm{M}$ [81-83]. Multiple investigations were carried out, such as control-specific binding at $50 \%$ of human 5 -HT7 (84\%) sites with an IC50s value of $1.2 \mu \mathrm{M}$; IC50s at H1(61\%), with an IC value of $5.3 \mu \mathrm{M}$; and human 5-HT1A $(91 \%)$ with a IC50s value of $1.5 \mu \mathrm{M}$. c-Met knockdown cells show shMet-A $(95 \% \mathrm{CI}=4-4.5)$ tumor growth retardation with up to $60 \mu \mathrm{M}$ Veliparib (ABT-888) [81-83]. When treated with $38 \mu \mathrm{M}$ Veliparib, c-Met knockdown cells show shMet-B (95\% CI $=1.3-2.5)$ tumor growth inhibition. Cell viability was higher with $1,000 \mu \mathrm{M}$ sulfur mustard (SM) exposure in HaCaT cells at $6 \mathrm{~h}$ post-treatment by Veliparib [81-83]. Additionally, Veliparib no longer shows protective effects at $24 \mathrm{~h}$ post SM exposure.

Randomized patients were selected to receive either paclitaxel as monotherapy or veliparib and carboplatin as a combination therapy, followed by doxorubicin and cyclophosphamide given in four cycles [83]. Clinical outcomes were examined, with estimated rates of PCR of $51 \%$ in the combination group with TNBC patients and $26 \%$ in the control group of patients [83]. For the phase III clinical trial, 634 patients were selected based on histological clinical stage II-III TNBC with no previous therapy for potentially curative surgery-they were randomly assigned to two groups; group I was treated with $50 \mathrm{mg}$ veliparib orally twice a day, with 12 weekly doses of $80 \mathrm{mg} / \mathrm{m}^{2}$ intravenous paclitaxel, and carboplatin administered every 3 weeks, for 4 cycles [81-83]. Patients with a germline $B R C A$ mutation were then allocated to group II and administered cyclophosphamide and doxorubicin every 2-3 weeks for 4 rounds [82]. Effective clinical outcomes were observed to be higher in $53 \%$ of patients with combined therapies in comparison to patients who received paclitaxel alone (31\%). No significant toxicity was observed against Veliparib. [81-83].

\subsection{Talazoparib (BMN-673)}

Talazoparib is a PARP inhibitor that is hypothesized to have a higher effectiveness than olaparib due to the process of PARP trapping, in which a PARP molecule is trapped on the DNA, inhibiting cell division [84]. Talazoparib is a dual-mechanism PARP inhibitor that traps PARP on DNA $[84,85]$. The phase II study ABRAZO evaluated the efficacy of talazoparib on inpatients with germline $B R C A 1 / 2$ mutations before being treated with platinum or multiple regimens $[84,85]$. Clinical efficacy was evaluated in TNBC/HR+ patients at $26 \% / 29 \%$; adverse effects were observed such as neutropenia, thrombocytopenia, anemia, fatigue, nausea, and diarrhea [85]. A phase III clinical trial was performed to compare the efficacy and safety of talazoparib in TNBC patients [84-86]. Clinical efficacy was observed-median PFS was 8.6 months for talazoparib, with a $46 \%$ reduction in the tumor, and 5.6 months for chemotherapies such as capecitabine, eribulin, gemcitabine, or vinorelbine [84-86]. All key secondary efficacy endpoints (OS, ORR, clinical benefit rate at 24 weeks) demonstrated benefits with talazoparib [85,86]. The PARP inhibitor was generally well tolerated, with minimal non-hematologic toxicity and few adverse events associated with treatment discontinuations [84-86]. Patients were treated with an anthracycline, with or without taxane as a neoadjuvant [84]; its primary clinical efficacy was examined, with PFS performed according to RECIST 1.1 criteria: median PFS was 8.6 and 5.6 months in the talazoparib and chemotherapy arms, respectively (HR 0.54; 95\% CI: 0.41, 0.71; $p<0.0001)[85,86]$. Its clinical approval was considered in EMBRACA (NCT01945775), an open label trial randomizing 431 patients (2:1) who were gBRCAm HER2-negative to treatment with talazoparib $(1 \mathrm{mg})$ with no more than 3 prior cytotoxic chemotherapy treatments for metastatic disease. Talazoparib was approved by the FDA for germline BRCA-mutated (gBRCAm), HER2-negative locally advanced or metastatic breast cancer. The FDA also approved the BRAC Analysis CDx test for identifying patients with breast cancer with deleterious or suspected deleterious $g B R C A \mathrm{~m}$ who are eligible for talazoparib [85].

\subsection{Rucaparib}

Rucaparib is an effective inhibitor of PARP1, PARP-2, and PARP-3 in BRCA-mutated patients (germline and/or somatic). Rucaparib was also found to be effective in HR- 
deficient patients [87]. Rucaparib is indicated as a monotherapy treatment for adults who are platinum-sensitive, patients who have been treated with two or more prior lines of platinum-based chemotherapy, and for those who are unable to tolerate further platinumbased chemotherapy [88]. A multicenter phase clinical trial was performed to establish $B R C A 1 / 2$ mutations and earlier treatment with rucaparib. Intravenous, and subsequently oral, rucaparib were evaluated with different dose concentrations [89]. Efficacy and safety levels were evaluated, such as pharmacodynamics, pharmacokinetic dose-limiting toxic effects, and tolerability [90]. Intravenous rucaparib was given and the objective response rate was analyzed: $41 \%$ of patients showed an ongoing response for at least 12 weeks [91]. The efficacy and safety of rucaparib in patients with HER2-negative metastatic breast cancer were associated with BRCAness phenotype and/or a somatic BRCA mutations [87-91]. Patients received $600 \mathrm{mg}$ rucaparib orally for 21 days or up to the development of the disease. The main endpoint was the clinical benefit rate and secondary endpoints, including PFS, overall survival, safety, and the prognostic value of the BRCAness signature [87-91]. An additional study determined the quantity of sporadic TNBC patients likely to benefit from rucaparib treatment [87-91].

\subsection{Checkpoint Inhibitors}

TNBC is pushing to improve treatment by answering questions regarding biomarkers of response, defining the utility of neoadjuvant approaches, and exploring potential combinations of checkpoint inhibitors and PARP inhibitors. The FDA approved the nabpaclitaxel (Abraxane) with atezolizumab (Tecentriq) for patients with metastatic PD-L1positive TNBC. The approval was based on the phase 3 IMpassion130 trial (NCT02425891), which established a $38 \%$ decrease in the risk of disease development with the combination vs. placebo plus nab-paclitaxel in this patient population. Pembrolizumab is a second approved checkpoint inhibitor drug, approved by the FDA in Nov 2020, for patients with metastatic TNBC whose tumors express a PD-L1 combined positive score (CPS) of 10 or higher, as determined by an FDA-approved test. Pembrolizumab also demonstrated proof of concept as a neoadjuvant based on findings from the phase II I-SPY2 trial (NCT01042379); pembrolizumab neoadjuvant plus chemotherapy extended pathologic complete response $(\mathrm{pCR})$ rates by 13.6 percentage points compared with chemotherapy alone for patients with early TNBC (95\% CI, 5.4-21.8; $p<0.001)$.

\section{PARP Inhibitor Resistance}

BRCA1 and 2-deficient cancer cells are sensitive to PARP inhibitors (PARPi); various PAPRi have been permitted for treatment of BC $[53,89,90]$. Nevertheless, PARPi resistance has been observed during patient treatment. Most $B R C A 1 / 2$-deficient patients fail to respond to PARPi with prolonged treatment [90]. In PARPi, HRD plays an essential role in preventing the growth of tumor cells. Researchers from the field have reported that DNA replication fork protectors are also involved in PARPi resistance in BRCA1/2deficient patients [89-91]. Therefore, various factors are responsible for resistance, such as epigenetic modification, restoration of ADP-ribosylation, pharmacological alteration, and reversion mutations.

\subsection{Restoration of HR Repair in PARPi Resistance}

HR dominates in the S/G2 cell cycle due to the high DNA replication [92]. The DSB ends are firstly resected by the MRN (Mre11-Rad50-Nbs1) complex with EXO1, DNA2, and MUS8, leading to the development of the ssDNA and pushing the cells towards HR $[92,93]$. Subsequently, the resected DNA ends are coated by the hyperphosphorylated single-stranded DNA binding protein A (RPA) [94,95]. The variant $H 2 A X$ is stimulated and phosphorylated by apical kinases, such as ATM and ATR (ATM and Rad3-related). The distribution of $\gamma H 2 A X$ on the chromosome promotes the accumulation of additional DDR proteins, including 53BP1 (p53-binding protein) and BRCA1 to the DDR foci $[55,95]$. With the help of $P A L B 2, B R C A 2$ binds with $B R C A 1$ and promotes the loading of recombinase 
RAD51 on the ssDNA [95]. Hence, the repair of the HR pathway via encouragement of DNA end resection and development of nucleoprotein filaments and D-loops can promote PARPi resistance [92-95].

\subsection{DNA end Resection in PARPi Resistance}

CDK12 deletion is responsible for PARPi resistance in TNBC patients; CDKs prevent DNA end resection and lead to PARPi resistance [96]. Most PARPi and CDK inhibitors are used by clinicians [97]. In DNA end resection, PARPi resistance may occur due to some important factors of the cell cycle, as well as CDKs, such as RIF1, REV7, and 53BP1 [98]. Chromatin-binding protein (53BP1) plays a very important role in blocking DNA resectioning by controlling CtIP transport to DSB sites, leading to PARPi resistance [99]. 53BP1 is responsible for DNA ends shielding in two pathways: firstly, by supporting the nucleosomal blockade of end-resection nucleases by H4K20m2 and H2AK15ub. In the second pathway, the effector protein complex is responsible for protecting DNA ends such as REV7, SHLD1, SHLD2, and SHLD3 with the help of 53BP1 and RIF1 [98,99]. NHEJ repair and HR repair mechanisms are also linked with PARPi resistance, with REV7 mainly responsible for sensitizing cells to PARPi. Conformational changes occur in REV7, linked with TRIP13 ATPase-promoted HR-leading to PARPi resistance [11,96]. The protective role of 53BP1 has required the interaction with PTIP and RIF1, which is dependent on ATM [98,99]. Therefore, the combined interaction of 53BP1 and RIF1 is involved in DNA end resection and PARPi resistance.

\subsection{Formation of RAD51-ssDNA Filament and D-Loop in PARPi Resistance}

RAD51-ssDNA plays an important role in HR repair, and RAD51 acts as a biomarker for HR repair and PAPRi resistance in patients with BRCA mutations $[48,92,96]$. EMI1 has been recognized as an essential target of RAD51 and modulator of PARPi activity [48,92]. PARPi resistance in BRCA1-deficiency occurs in TNBC cells due to downregulation of EMI, leading to accumulation of RAD51 [96]. In TNBC cells, RAD51 degradation occurs due to DDB2 (damaged DNA binding protein) and DNA damage recognition factor $[48,96]$. Defective HR and sensitivity to PARPi inhibit DDB2-induced RAD51 polyubiquitination. RAD51 phosphorylation takes place in the presence of TOPBP1 (topoisomerase II $\beta$-binding protein) $[48,92,96]$. Another protein, $B R D 4$ (bromodomain protein 4 ) is responsible for genome stability; the inhibition of $B R D 4$ causes the aggregation of $R A D 51$, lacking stimulation by the ATR-dependent/ATM DNA damage response [96,100,101]. DBRD4 inhibitors (JQ1, INCB054329) increase the activity of PARPi. APRIN and PALB2 to favorably bind to D-loop constructions and directly interact with RAD51 to activate HR. It has been shown that deletion of APRIN and PALB2 stimulates BRCAness and directs PARPi to cells $[100,101]$. Furthermore, Pol $\delta$ assists in D-loop development and amplifies the activity of HR-proficient cancer cells in response to PARPi [100,101].

\section{Reversion Mutations in PARPi Resistance}

Researchers investigated the effects of reversion mutations on PARPi resistance in 2008 in a BRCA2- deficient cell line and found that the reconstructed BRCA2-deficient cells developed PARPi resistance $[63,67,91]$. Wild-type recessive mutations were restored; the $B R C A 2$ reading frame is an important intermediary of acquired resistance to platinum and PARPi [91]. Multiple BRCA reversion mutations were identified by employing liquid biopsy and cfDNA (circulating cell-free DNA) to re-establish BRCA1/2 mutations, resulting in PARPi resistance $[63,67]$. Recently, two reversion mutations were identifiedc.4897_6807del and c.4434_5686delinsTT truncated BRCA2 protein—which were supposed to be capable of causing PARPi resistance $[63,67,91,92]$.

\subsection{Protection of the DNA Replication Fork in PARPi Resistance}

$B R C A 1$ and $B R C A 2$ protect newly synthesized DNA at delayed repetition forks from MRE11/DNA2-dependent decay [102]. As BRCA1/2 is damaged, the lack of DNA replica- 
tion fork protection causes genome instability and cell death-but at the same time, HR is not caused by PARPi resistance in patients with BRCA1/2 [95,99]. MRE11-mediated fork degradation is suppressed by FANCD2; FANCD2 is observed in BRCA1/2-mutated BC. Overexpression of FANCD2 leads to resistance to PARPi [101,102]. RADX deletion reinstates fork protection but not HR, by modifying $R A D 51$ at replication forks and restoring PARPi sensitivity in BRCA2-mutations [96]. Therefore, its strength lies in bringing a novel approach to the future of cancer therapy. Delayed replication divergences are the main foundation of genome variability in multiplying cells, which is essential to maintain cell viability [38,95]. Pathways involved in ATR/CHK1-dependent checkpoint activation and RecQ helicases also play essential roles in replication fork protection and genome stability maintenance $[48,49]$. Therefore, they might function as part of the mechanisms of PARPi resistance. However, there are no relevant preclinical or clinical studies up to now, which are expected to be taken into consideration in the future.

\subsection{Epigenetic Modification, Restoration of PARylation, and Pharmacological Alteration in PARPi Resistance}

PARPi efficacy may be affected by epigenetic modifications; various lines of therapy are received by patients before PARPi treatment, leading to reduced $B R C A$ expression and causing PARPi resistance [59]. NHEJ repair is suppressed by MiR-622 and miR-493-5p by altering multiple pathways relevant to genome solidity $[31,73,99,100]$. Deubiquitination of the BARD1 BRCT domain by USP15 supports BRCA1 retention at DSBs and causes PARPi resistance $[100,101]$. Most of these modifications take place similarly through acetylation of 53 bp1-repressed NHEJ and promotion of HR by undesirable alterations in 53 bp1 recruitment to DSBs, leading to BRCA1-deficient cells developing resistance to PARPi. m6A (N6-methyladenosine) plays an important role in PARPi resistance [100-102]; increased expression of m6A in PEO1 cells has been established. c-Met mediates the phosphorylation of PARP1 at the position of Tyr907, leading to drug resistance to PARPi [94,103]. BRCA2mutated animal models develop mammary tumors [84,85]. Increased expression levels of P-gp-mediated drug efflux are involved in resistance to PARPi, validated using in vivo and in vitro investigations; this resistance may be reversed by adding regimens of $\mathrm{P}$-gP inhibitors [104]. Long-term overexpression of ABCB1 leads to changes in pharmacokinetic properties and causes PARPi resistance [104].

\section{Clinical Implications of PARPi Resistance}

Effective clinical strategies and increasing PARPi sensitivity may overcome drug resistance $[37,49,58,79]$. oHSV (PARPioncolytic herpes simplex virus) combination treatments are approved by the FDA for frequent melanoma, and are inherently engineered to selectively kill cancer cells, due to their characteristics of amplifying and spreading within the tumor but not normal tissue [105]. They are actively involved in manipulating DDR [105]. The combination treatment of MG18L with olaparib significantly improved efficacy in both PARPi-sensitive and -resistant GSC-derived tumors [29,56,63-65]. MG18L detects proteasomal damage to RAD51, explaining glioblastoma stem cells' (GSCs') susceptibility to killing by PARPi in a synthetic lethal-like fashion in vivo and in vitro [48,92]. Combination therapy is recommended to enhance the efficacy of PARPi-ionizing radiation (PI) and nuclear localization (NL) [48]. NL is essential for BRCA1 to contribute to HRfacilitated DNA repair [14]. PARPi encourages radiosensitization in animal models as well as in cell lines; increased radiosensitivity in preclinical model systems was observed due to HR restoration by 53BP1 pathway inactivation $[31,37,40,99]$. Stimulating HR restoration via 53BP1 pathway inactivation further enhanced radiosensitivity in preclinical model systems $[40,99]$. It was observed that BRCA1-mutated tumors lead to drug resistance due to BRCA1-independent HR restoration and are sensitized to radiotherapy [31,37,40]. Clinical investigations (NCT00649207) similarly trying to identify the efficacy of PARPi-IR combination with veliparib in Phase I observed a more clinically effective outcome [40,80-83]. A randomized, controlled phase IIb study has been carried out. Two other phase I trials (NCT01264432, NCT01589419) indicated that PARPi-IR combination treatment was 
well-tolerated and showed good responses as well. Patients received veliparib PO BID on days 1-21 (days 5-21 of course 1). Patients underwent LDFWAR in BID on days 1 and 5 of weeks $1-3$ [40,80-83]. Treatment were repeated every 28 days for 3 courses in the absence of disease progression or unacceptable toxicity [40,80-83]. CDK inhibitor was re-sensitized in TBNC cells with dinaciclib, previously reported as being resistant to niraparib $[97,98]$. CDK12 is involved in PARPi resistance by inactivating somatic alterations; CDK12 mutations lead to sensitivity to PARPi $[97,98]$. CDK12 inhibitors are reversed by de novo and attained PARPi resistance in BRCA1-mutant BC cells $[97,98]$. PARPi has also been used in combination with HSP90 inhibitors, WEE1 inhibitors, and ATR/CHK1 inhibitors [49]. HSP90 plays an important role in BRCA1 function [49]. HSP90 inhibitor (7-dimethylaminoethylamino-17-demethoxygeldanamycin) reverses the resistance state by decreasing the quantity of $B R C A 1$ protein. WEE1 inhibitors and ATR/CHK1 treatment also play an important role in reversing PARPi resistance [49]. Various clinical trials are going on to evaluate the safety and efficacy of combination therapy for clinical implementation, such as NCT03787680, NCT03330847, NCT03878095, NCT03462342, NCT03428607, NCT03682289, NCT03579316, NCT04197713, NCT02576444, NCT02511795, and NCT04 065269 [3].

\section{CRISPR/Cas9 in Reverse Mutation}

CRISPR/Cas9 technology has facilitated an attractive paradigm shift in gene editing for clinical and therapeutic intervention through the generation of various CRISPR/Cas9based high-throughput screens [106]. For instance, this technology has been used for the efficient replacement of hotspot mutation regions, which leads to the suppression of tumor progression, reduction of drug resistance, and improvement of drug efficiency $[107,108]$. CRISPR/Cas9-mediated technology could be used to reverse the resistance factor, by targeting mutations caused by genetic heterogenicity at DNA repair pathways, the BER mechanism, HR, and NEJ deficiency-based repair mechanisms [107]. Experts from the field have enhanced the efficacy of PARPi resistance proteins by using CRISPR/Cas9 [108]. A researcher from the field exhibited that combination of mild hyperthermia, Olaparib, an HSP90 inhibitor, and 17-(dimethylaminoethylamino)-17-demthoxygeldanamycin (17DMAG) led to a complete loss of tumor growth $[3,107,108]$. For instance, all of the mice treated with this combination survived during the treatment [107]. On the contrary, the survival of mice who received a treatment of hyperthermia and PARP inhibitors was about $36 \%$ [97]. High-throughput analyses of the CRISPR/Cas9-based library are used to analyze mutations for clinical drug resistance with high sensitivity and specificity [108]. The histone acetyltransferase (HAT) enzyme catalyzes the reaction of adding acetyl groups to lysine residues on histone complexes. HDI-treated cells become responsive to PARP inhibition because of the BRCAness effect [47]. First, HDI blocks the deacetylation of the HSP90 heat shock protein, which leads to hyperacetylation and inhibition of HSP90 [49,97,98]. As a result, several client proteins of HSP90 including BRCA1, RAD52, ATR, and CHK1 cannot interact with it $[49,97,98]$. In triple-negative breast cancer, treatment of HDI induces $B R C A$ ness and inhibits stemness for sensitization to PARP inhibitors $[47,49,97,98]$. Moreover, recent studies showed that HDI suberoylanilide hydroxamic acid (Vorinostat, SAHA), PARPi, and PJ34, synergistically induce cell death in anaplastic thyroid carcinoma and leukemia cells [54,92]. CRISPR/Cas9-mediated screening has been used to identify candidates involved in paclitaxel-resistant TNBCs [108]. In vitro and in vivo genetic and cellular analyses have elucidated the essential role of the MITR/MEF2A/IL11 axis in paclitaxel resistance and have provided a novel therapeutic strategy for TNBC patients to overcome poor chemotherapy responses [107-109]. Resistance to PARPi greatly hinders therapeutic effectiveness in TNBC; the mechanisms of PARPi resistance, including increased expression of MDR1, dissociation of PARP1 and PARG, HR restoration, and restoration of replication fork stalling, all reverse the DNA replication pressure and lower the sensitivity to PARPi treatment $[84,94,103,104]$. The CRISPR/Cas9-based approach could be useful in generating a knockout or knock-in TNBC genome and reversing drug resistance [107,109]. 


\section{Conclusions}

TNBC tumors are established by their mutual histopathologic and genetic characteristics. The conventional treatment presently prescribed in hospitals for TNBC depends primarily on the clinical stage of the disease and tolerability to treatment-usually accompanied by corticosteroids (dexamethasone) and drugs to control symptoms (ondansetron, etc.) to reduce adverse effects such as inhibition of DNA and RNA synthesis, inhibition of the topoisomerase II enzyme, generation of free oxygen radicals, induction of histone eviction from chromatin, etc. High-level genomic diversity is shown by BRCA1-associated cancers and sporadic triple-negative tumors, which can repair DNA damage. Sporadic TNBC tumors and $B R C A$ associated cancers are high grade and have $p 53$ tumor suppressor gene mutations, overexpression of the epidermal growth factor receptor, and resistance to chemotherapy, ineffective hormonal therapy, and HER2-directed therapy, due to the triplenegative nature of the disease. PARP inhibition and platinum compounds are effective treatment options for TNBC with HR deficiency. PARP-based monotherapy is unlikely to encourage cancer cell death in BRCA-proficient tumors-the optimal chemotherapeutic option for the future remains the combination of PARP inhibition with either cytotoxic drugs or impairment of mechanisms of DNA repair. In BRCA-deficient tumors, monotherapy with a PARP inhibitor is already an effective therapeutic approach that proves the concept of synthetic lethality.

Author Contributions: D.D.S. conceived and designed the project, D.K.Y. and A.P. collected data from the literature. D.D.S. analyzed the data and wrote the manuscript. All authors have read and agreed to the published version of the manuscript.

Funding: D.K.Y. and A.P. were thankful to the Basic Science Research Program of the National Research Foundation of Korea (NRF), funded by the Ministry of Education, Science, and Technology, who supported this study (No. 2017R1C1B2003380 and NRF2019R1G1A1003693).

Acknowledgments: D.D.S. is thankful to Amity Institute of Biotechnology, Amity University Rajasthan, Jaipur, India. D.K.Y. and A.P. are thankful to the Gachon Institute of Pharmaceutical Science and the Department of Pharmacy, College of Pharmacy, Gachon University of Medicine and Science, Incheon, Korea for providing the computational modeling facility.

Conflicts of Interest: The authors declare that the research was conducted in the absence of any commercial or financial relationships that could be construed as a potential conflict of interest.

\section{References}

1. Bray, F.; Ferlay, J.; Soerjomataram, I.; Siegel, R.L.; Torre, L.A.; Jemal, A. Global cancer statistics 2018: GLOBOCAN estimates of incidence and mortality worldwide for 36 cancers in 185 countries. CA Cancer J. Clin. 2018, 68, 394-424. [CrossRef]

2. Rummel, S.K.; Lovejoy, L.; Shriver, C.D.; Ellsworth, R.E. Contribution of germline mutations in cancer predisposition genes to tumor etiology in young women diagnosed with invasive breast cancer. Breast Cancer Res. Treat. 2017, 164, 593-601. [CrossRef] [PubMed]

3. Singh, D.D.; Yadav, D.K. TNBC: Potential Targeting of Multiple Receptors for a Therapeutic Breakthrough, Nanomedicine, and Immunotherapy. Biomedicines 2021, 9, 876. [CrossRef] [PubMed]

4. Medina, M.A.; Oza, G.; Sharma, A.; Arriaga, L.G.; Hernández Hernández, J.M.; Rotello, V.M.; Ramirez, J.T. Triple-Negative Breast Cancer: A Review of Conventional and Advanced Therapeutic Strategies. Int. J. Environ. Res. Public Health 2020, $17,2078$. [CrossRef]

5. Lee, K.-L.; Chen, G.; Chen, T.-Y.; Kuo, Y.-C.; Su, Y.-K. Effects of Cancer Stem Cells in Triple-Negative Breast Cancer and Brain Metastasis: Challenges and Solutions. Cancers 2020, 12, 2122. [CrossRef] [PubMed]

6. Lee, K.-L.; Kuo, Y.-C.; Ho, Y.-S.; Huang, Y.-H. Triple-Negative Breast Cancer: Current Understanding and Future Therapeutic Breakthrough Targeting Cancer Stemness. Cancers 2019, 11, 1334. [CrossRef]

7. Nederlof, I.; Horlings, H.; Curtis, C.; Kok, M. A High-Dimensional Window into the Micro-Environment of Triple Negative Breast Cancer. Cancers 2021, 13, 316. [CrossRef]

8. Keung, M.Y.T.; Wu, Y.; Vadgama, J.V. PARP Inhibitors as a Therapeutic Agent for Homologous Recombination Deficiency in Breast Cancers. J. Clin. Med. 2019, 8, 435. [CrossRef]

9. Schettini, F.; Giudici, F.; Bernocchi, O.; Sirico, M.; Corona, S.P.; Giuliano, M.; Locci, M.; Paris, I.; Scambia, G.; De Placido, S.; et al. Poly (ADP-ribose) polymerase inhibitors in solid tumours: Systematic review and meta-analysis. Eur. J. Cancer 2021, 149, 134-152. [CrossRef] 
10. Gourley, C.; Balmaña, J.; Ledermann, J.A.; Serra, V.; Dent, R.; Loibl, S.; Pujade-Lauraine, E.; Boulton, S.J. Moving From Poly (ADP-Ribose) Polymerase Inhibition to Targeting DNA Repair and DNA Damage Response in Cancer Therapy. J. Clin. Oncol. 2019, 37, 2257-2269. [CrossRef]

11. van Beek, L.; McClay, É.; Patel, S.; Schimpl, M.; Spagnolo, L.; de Oliveira, T.M. PARP Power: A Structural Perspective on PARP1, PARP2, and PARP3 in DNA Damage Repair and Nucleosome Remodelling. Int. J. Mol. Sci. 2021, 22, 5112. [CrossRef]

12. Langelier, M.-F.; Planck, J.L.; Roy, S.; Pascal, J.M. Structural Basis for DNA Damage-Dependent Poly(ADP-Ribosyl)Ation by Human PARP-1. Science 2012, 336, 728-732. [CrossRef] [PubMed]

13. Pascal, J.M. The Comings and Goings of PARP-1 in Response to DNA Damage. DNA Repair 2018, 71, 177-182. [CrossRef]

14. Wang, Y.; Luo, W.; Wang, Y. PARP-1 and Its Associated Nucleases in DNA Damage Response. DNA Repair 2019, 81, 102651. [CrossRef] [PubMed]

15. Van Andel, L.; Zhang, Z.; Lu, S.; Kansra, V.; Agarwal, S.; Hughes, L.; Tibben, M.M.; Gebretensae, A.; Lucas, L.; Hillebrand, M.J.X.; et al. Human mass balance study and metabolite profiling of 14Cniraparib, a novel poly(ADP-Ribose) polymerase (PARP)-1 and PARP-2 inhibitor, in patients with advanced cancer. Investig. New Drugs 2017, 35, 751-765. [CrossRef] [PubMed]

16. Fong, P.C.; Boss, D.S.; Yap, T.A.; Tutt, A.; Wu, P.; Mergui-Roelvink, M.; Mortimer, P.; Swaisland, H.; Lau, A.; O'Connor, M.J.; et al. Inhibition of Poly(ADP-Ribose) Polymerase in Tumors from BRCA Mutation Carriers. N. Engl. J. Med. 2009, 361, 123-134. [CrossRef]

17. Virtanen, V.; Paunu, K.; Ahlskog, J.K.; Varnai, R.; Sipeky, C.; Sundvall, M. PARP Inhibitors in Prostate Cancer-The Preclinical Rationale and Current Clinical Development. Genes 2019, 10, 565. [CrossRef]

18. Kraus, W.L. PARPs and ADP-Ribosylation: 50 Years ... and counting. Mol. Cell 2015, 58, 902-910. [CrossRef]

19. Cohen, M.S.; Chang, P. Insights into the Biogenesis, Function, and Regulation of ADP-Ribosylation. Nat. Chem. Biol. 2018, 14, 236-243. [CrossRef]

20. Langelier, M.-F.; Ruhl, D.D.; Planck, J.L.; Kraus, W.L.; Pascal, J.M. The Zn3 Domain of Human Poly(ADP-Ribose) Polymerase-1 (PARP-1) Functions in Both DNA-Dependent Poly(ADP-Ribose) Synthesis Activity and Chromatin Compaction. J. Biol. Chem. 2010, 285, 18877-18887. [CrossRef]

21. Barkauskaite, E.; Jankevicius, G.; Ahel, I. Structures and Mechanisms of Enzymes Employed in the Synthesis and Degradation of PARP-Dependent Protein ADP-Ribosylation. Mol. Cell 2015, 58, 935-946. [CrossRef]

22. Hoch, N.C.; Polo, L.M. ADP-Ribosylation: From Molecular Mechanisms to Human Disease. Genet. Mol. Biol. 2020, 43 , e20190075. [CrossRef]

23. Durkacz, B.W.; Omidiji, O.; Gray, D.A.; Shall, S. (ADP-Ribose)n Participates in DNA Excision Repair. Nature 1980, $283,593-596$. [CrossRef]

24. Rudolph, J.; Mahadevan, J.; Luger, K. Probing the Conformational Changes Associated with DNA Binding to PARP1. Biochemistry 2020, 59, 2003-2011. [CrossRef] [PubMed]

25. Bilokapic, S.; Suskiewicz, M.J.; Ahel, I.; Halic, M. Bridging of DNA Breaks Activates PARP2-HPF1 to Modify Chromatin. Nature 2020, 585, 609-613. [CrossRef] [PubMed]

26. Eisemann, T.; Pascal, J.M. Poly(ADP-Ribose) Polymerase Enzymes and the Maintenance of Genome Integrity. Cell. Mol. Life Sci. 2020, 77, 19-33. [CrossRef] [PubMed]

27. Zandarashvili, L.; Langelier, M.-F.; Velagapudi, U.K.; Hancock, M.A.; Steffen, J.D.; Billur, R.; Hannan, Z.M.; Wicks, A.J.; Krastev, D.B.; Pettitt, S.J.; et al. Structural Basis for Allosteric PARP-1 Retention on DNA Breaks. Science 2020, 368, eaax6367. [CrossRef]

28. Sukhanova, M.V.; Hamon, L.; Kutuzov, M.M.; Joshi, V.; Abrakhi, S.; Dobra, I.; Curmi, P.A.; Pastre, D.; Lavrik, O.I. A SingleMolecule Atomic Force Microscopy Study of PARP1 and PARP2 Recognition of Base Excision Repair DNA Intermediates. J. Mol. Biol. 2019, 431, 2655-2673. [CrossRef]

29. Andreidesz, K.; Koszegi, B.; Kovacs, D.; Bagone Vantus, V.; Gallyas, F.; Kovacs, K. Effect of Oxaliplatin, Olaparib and LY294002 in Combination on Triple-Negative Breast Cancer Cells. Int. J. Mol. Sci. 2021, 22, 2056. [CrossRef]

30. Dirix, L.; Swaisland, H.; Verheul, H.M.; Rottey, S.; Leunen, K.; Jerusalem, G.; Rolfo, C.; Nielsen, D.; Molife, L.R.; Kristeleit, R.; et al. Effect of itraconazole and rifampin on the pharmacokinetics of olaparib in patients with advanced solid tumors: Results of two phase I open-label studies. Clin. Ther. 2016, 38, 2286-2299. [CrossRef]

31. Ensminger, M.; Löbrich, M. One end to rule them all: Non-homologous end-joining and homologous recombination at DNA double-strand breaks. Br. J. Radiol. 2020, 93, 20191054. [CrossRef] [PubMed]

32. Plummer, R.; Swaisland, H.; Leunen, K.; Van Herpen, C.M.L.; Jerusalem, G.; De Greve, J.; Lolkema, M.P.; Soetekouw, P.; MauSørensen, M.; Nielsen, D.; et al. Olaparib tablet formulation: Effect of food on the pharmacokinetics after oral dosing in patients with advanced solid tumours. Cancer Chemother. Pharmacol. 2015, 76, 723-729. [CrossRef] [PubMed]

33. Blackford, A.N.; Jackson, S.P. ATM, ATR, and DNA-PK: The Trinity at the heart of the DNA damage response. Mol. Cell 2017, 66, 801-817. [CrossRef] [PubMed]

34. Mostafa, N.M.; Chiu, Y.L.; Rosen, L.S.; Bessudo, A.; Kovacs, X.; Giranda, V.L. A phase 1 study to evaluate effect of food on veliparib pharmacokinetics and relative bioavailability in subjects with solid tumors. Cancer Chemother. Pharmacol. 2014, 74, 583-591. [CrossRef]

35. Diana, A.; Carlino, F.; Franzese, E.; Oikonomidou, O.; Criscitiello, C.; De Vita, F.; Ciardiello, F.; Orditura, M. Early Triple Negative Breast Cancer: Conventional Treatment and Emerging Therapeutic Landscapes. Cancers 2020, 12, 819. [CrossRef] 
36. Min, A.; Kim, K.; Jeong, K.; Choi, S.; Kim, S.; Suh, K.J.; Lee, K.-H.; Kim, S.; Im, S.-A. Homologous repair deficiency score for identifying breast cancers with defective DNA damage response. Sci. Rep. 2020, 10, 12506. [CrossRef]

37. O'Connor, L.O.; Rulten, S.L.; Cranston, A.N.; Odedra, R.; Brown, H.; Jaspers, J.E.; Jones, L.; Knights, C.; Evers, B.; Ting, A.; et al. The PARP Inhibitor AZD2461 Provides Insights into the Role of PARP3 Inhibition for Both Synthetic Lethality and Tolerability with Chemotherapy in Preclinical Models. Cancer Res. 2016, 76, 6084-6094.

38. Harrision, D.; Gravells, P.; Thompson, R.; Bryant, H.E. Poly(ADP-Ribose) Glycohydrolase (PARG) vs. Poly(ADP-Ribose) Polymerase (PARP)-Function in Genome Maintenance and Relevance of Inhibitors for Anti-Cancer Therapy. Front. Mol. Biosci. 2020, 7, 21. [CrossRef]

39. Madeira, F.; Park, Y.M.; Lee, J.; Buso, N.; Gur, T.; Madhusoodanan, N.; Basutkar, P.; Tivey, A.R.N.; Potter, S.C.; Finn, R.D.; et al. The EMBL-EBI Search and Sequence Analysis Tools APIs in 2019. Nucleic Acids Res. 2019, 47, W636-W641. [CrossRef]

40. Tuli, R.; Shiao, S.L.; Nissen, N.; Tighiouart, M.; Kim, S.; Osipov, A.; Bryant, M.; Ristow, L.; Placencio-Hickok, V.; Hoffman, D.; et al. A Phase 1 Study of Veliparib, a PARP-1/2 Inhibitor, with Gemcitabine and Radiotherapy in Locally Advanced Pancreatic Cancer. EBioMedicine 2019, 40, 375-381. [CrossRef]

41. Lee, J.; Liu, H.; Pearson, T.; Iwase, T.; Fuson, J.; Lalani, A.S.; Eli, L.D.; Diala, I.; Tripathy, D.; Lim, B.; et al. PI3K and MAPK Pathways as Targets for Combination with the Pan-HER Irreversible Inhibitor Neratinib in HER2-Positive Breast Cancer and TNBC by Kinome RNAi Screening. Biomedicines 2021, 9, 740. [CrossRef] [PubMed]

42. Ryu, W.-J.; Sohn, J.H. Molecular Targets and Promising Therapeutics of Triple-Negative Breast Cancer. Pharmaceuticals 2021, 14, 1008. [CrossRef]

43. Lehmann, B.D.; Bauer, J.A.; Schafer, J.M.; Pendleton, C.S.; Tang, L.; Johnson, K.C.; Chen, X.; Balko, J.M.; Gomez, H.; Arteaga, C.L.; et al. PIK3CA mutations in androgen receptor-positive triple negative breast cancer confer sensitivity to the combination of PI3K and androgen receptor inhibitors. Breast Cancer Res. 2014, 16, 406. [CrossRef] [PubMed]

44. Yang, C.C.; LaBaff, A.; Wei, Y.; Nie, L.; Xia, W.; Huo, L.; Yamaguchi, H.; Hsu, Y.H.; Hsu, J.L.; Liu, D.; et al. Phosphorylation of EZH2 at T416 by CDK2 contributes to the malignancy of triple negative breast cancers. Am. J. Transl. Res. 2015, 7, 1009-1020. [PubMed]

45. Langelier, M.-F.; Riccio, A.A.; Pascal, J.M. PARP-2 and PARP-3 Are Selectively Activated by $5^{\prime}$ Phosphorylated DNA Breaks Through an Allosteric Regulatory Mechanism Shared with PARP-1. Nucleic Acids Res. 2014, 42, 7762-7775. [CrossRef] [PubMed]

46. Lord, C.J.; Ashworth, A. BRCAness revisited. Nat. Rev. Cancer 2016, 16, 110-120. [CrossRef]

47. Ogden, T.E.H.; Yang, J.-C.; Schimpl, M.; Easton, L.E.; Underwood, E.; Rawlins, P.B.; McCauley, M.M.; Langelier, M.-F.; Pascal, J.M.; Embrey, K.J.; et al. Dynamics of the HD Regulatory Subdomain of PARP-1; Substrate Access and Allostery in PARP Activation and Inhibition. Nucleic Acids Res. 2021, 49, 2266-2288. [CrossRef]

48. Choi, C.; Cho, W.K.; Park, S.; Shin, S.-W.; Park, W.; Kim, H.; Choi, D.H. Checkpoint Kinase 1 (CHK1) Inhibition Enhances the Sensitivity of Triple-Negative Breast Cancer Cells to Proton Irradiation via Rad51 Downregulation. Int. J. Mol. Sci. 2020, $21,2691$. [CrossRef]

49. Gorecki, L.; Andrs, M.; Korabecny, J. Clinical Candidates Targeting the ATR-CHK1-WEE1 Axis in Cancer. Cancers 2021, 13, 795. [CrossRef]

50. Nandini, D.; Jennifer, A.; Pradip, D. Therapeutic Strategies for Metastatic Triple-Negative Breast Cancers: From Negative to Positive. Pharmaceuticals 2021, 14, 455. [CrossRef]

51. Baldan, F.; Mio, C.; Allegri, L.; Puppin, C.; Russo, D.; Filetti, S.; Damante, G. Synergy between HDAC and PARP Inhibitors on Proliferation of a Human Anaplastic Thyroid Cancer-Derived Cell Line. Int. J. Endocrinol. 2015, 2015, 978371. [CrossRef]

52. Chu, P.-Y.; Tai, Y.-L.; Shen, T.-L. Grb7, a Critical Mediator of EGFR/ErbB Signaling, in Cancer Development and as a Potential Therapeutic Target. Cells 2019, 8, 435. [CrossRef]

53. Nagano, T.; Tachihara, M.; Nishimura, Y. Mechanism of Resistance to Epidermal Growth Factor Receptor-Tyrosine Kinase Inhibitors and a Potential Treatment Strategy. Cells 2018, 7, 212. [CrossRef]

54. Gilardini Montani, M.S.; Prodosmo, A.; Stagni, V.; Merli, D.; Monteonofrio, L.; Gatti, V.; Gentileschi, M.P.; Barila, D.; Soddu, S. ATM-depletion in breast cancer cells confers sensitivity to PARP inhibition. J. Exp. Clin. Cancer Res. 2013, 32, 95. [CrossRef] [PubMed]

55. Barlaam, B.; Pike, K. Identifying high quality, potent and selective inhibitors of ATM kinase: Discovery of AZD0156. Eur. J. Cancer 2016, 61, S118. [CrossRef]

56. Sari, M.; Saip, P. Myelodysplastic Syndrome after Olaparib Treatment in Heavily Pretreated Ovarian Carcinoma. Am. J. Ther. 2019, 26, e632-e633. [CrossRef] [PubMed]

57. Ungefroren, H. Autocrine TGF- $\beta$ in Cancer: Review of the Literature and Caveats in Experimental Analysis. Int. J. Mol. Sci. 2021, 22, 977. [CrossRef] [PubMed]

58. Brumec, M.; Sobočan, M.; Takač, I.; Arko, D. Clinical Implications of Androgen-Positive Triple-Negative Breast Cancer. Cancers 2021, 13, 1642. [CrossRef] [PubMed]

59. Luo, J.; Jin, J.; Yang, F.; Sun, Z.; Zhang, W.; Shi, Y.; Xu, J.; Guan, X. The correlation between PARP1 and BRCA1 in AR positive triple-negative breast cancer. Int. J. Biol. Sci. 2016, 12, 1500-1510. [CrossRef]

60. Traina, T.A.; Miller, K.; Yardley, D.A.; Eakle, J.; Schwartzberg, L.S.; O’Shaughnessy, J.; Gradishar, W.; Schmid, P.; Winer, E.; Kelly, C.; et al. Enzalutamide for the treatment of androgen receptor-expressing triple-negative breast cancer. J. Clin. Oncol. 2018, 36, 884-890. [CrossRef] 
61. Ke, Y.; Zhang, J.; Lv, X.; Zeng, X.; Ba, X. Novel Insights into PARPs in Gene Expression: Regulation of RNA Metabolism. Cell. Mol. Life Sci. 2019, 76, 3283-3299. [CrossRef] [PubMed]

62. Murai, J.; Huang, S.-Y.N.; Renaud, A.; Zhang, Y.; Ji, J.; Takeda, S.; Morris, J.; Teicher, B.; Doroshow, J.H.; Pommier, Y. Stereospecific PARP Trapping by BMN 673 and Comparison with Olaparib and Rucaparib. Mol. Cancer Ther. 2014, 13, 433-443. [CrossRef] [PubMed]

63. Robson, M.; Im, S.-A.; Senkus, E.; Xu, B.; Domchek, S.M.; Masuda, N.; Delaloge, S.; Li, W.; Tung, N.; Armstrong, A.; et al. Olaparib for Metastatic Breast Cancer in Patients with a Germline BRCA Mutation. N. Engl. J. Med. 2017, 377, 523-533. [CrossRef] [PubMed]

64. Nicolas, E.; Bertucci, F.; Sabatier, R.; Gonçalves, A. Targeting BRCA Deficiency in Breast Cancer: What are the Clinical Evidences and the Next Perspectives? Cancers 2018, 10, 506. [CrossRef]

65. Clarke, N.; Wiechno, P.; Alekseev, B.; Sala, N.; Jones, R.; Kocak, I.; Chiuri, V.E.; Jassem, J.; Flechon, A.; Redfern, C.; et al. Olaparib combined with abiraterone in patients with metastatic castration-resistant prostate cancer: A randomised, double-blind, placebo-controlled, phase 2 trial. Lancet Oncol. 2018, 19, 975-986. [CrossRef]

66. Robson, M.; Tung, N.; Conte, P.; Im, S.-A.; Senkus, E.; Xu, B.; Masuda, N.; Delaloge, S.; Li, W.; Armstrong, A.; et al. OlympiAD final overall survival and tolerability results: Olaparib versus chemotherapy treatment of physician's choice in patients with a germline BRCA mutation and HER2-negative metastatic breast cancer. Ann. Oncol. 2019, 30, 558-566. [CrossRef]

67. Pujade-Lauraine, E.; Ledermann, J.A.; Selle, F. Olaparib tablets as maintenance therapy in patients with platinum-sensitive, relapsed ovarian cancer and a BRCA1/2 mutation (SOLO2/ENGOT-Ov21): A double-blind, randomised, placebo-controlled, phase 3 trial. Lancet Oncol. 2017, 18, E510. [CrossRef]

68. Karzai, F.; VanderWeele, D.; Madan, R.A.; Owens, H.; Cordes, L.M.; Hankin, A.; Couvillon, A.; Nichols, E.; Bilusic, M.; Beshiri, M.L.; et al. Activity of durvalumab plus olaparib in metastatic castration-resistant prostate cancer in men with and without DNA damage repair mutations. J. Immunother. Cancer 2018, 6, 141. [CrossRef]

69. Nitecki, R.; Gockley, A.A.; Floyd, J.L.; Coleman, R.L.; Melamed, A.; Rauh-Hain, J.A. The incidence of myelodysplastic syndrome in patients receiving poly-ADP ribose polymerase inhibitors for treatment of solid tumors: A meta-analysis. J. Clin. Oncol. 2020, 38, 3641. [CrossRef]

70. Hossain, F.; Majumder, S.; David, J.; Miele, L. Precision Medicine and Triple-Negative Breast Cancer: Current Landscape and Future Directions. Cancers 2021, 13, 3739. [CrossRef]

71. Bergin, A.R.T.; Loi, S. Triple-negative breast cancer: Recent treatment advances. F1000Research 2019, 8, 1342. [CrossRef]

72. Pierce, A.; McGowan, P.M.; Cotter, M.; Mullooly, M.; O’Donovan, N.; Rani, S.; O’Driscoll, L.; Crown, J.; Duffy, M.J. Comparative antiproliferative effects of iniparib and olaparib on a panel of triple-negative and non-triple-negative breast cancer cell lines. Cancer Biol. Ther. 2013, 14, 537-545. [CrossRef]

73. Telli, M.L.; Timms, K.M.; Reid, J.; Hennessy, B.; Mills, G.B.; Jensen, K.C.; Szallasi, Z.; Barry, W.T.; Winer, E.P.; Tung, N.M.; et al. Homologous recombination deficiency (HRD) score predicts response to platinum-containing neoadjuvant chemotherapy in patients with triple-negative breast cancer. Clin. Cancer Res. 2016, 22, 3764-3773. [CrossRef]

74. Diéras, V.; Bonnefoi, H.; Alba, E.; Awada, A.; Coudert, B.; Pivot, X.; Gligorov, J.; Jager, A.; Zambelli, S.; Lindeman, G.J.; et al. Iniparib administered weekly or twice-weekly in combination with gemcitabine/carboplatin in patients with metastatic triplenegative breast cancer: A phase II randomized open-label study with pharmacokinetics. Breast Cancer Res. Treat. 2019, 177, 383-393. [CrossRef] [PubMed]

75. Mateo, J.; Ong, M.; Tan, D.S.; Gonzalez, M.A.; de Bono, J.S. Appraising iniparib, the PARP inhibitor that never was-What must we learn? Nat. Rev. Clin. Oncol. 2013, 10, 688-696. [CrossRef] [PubMed]

76. O'Shaughnessy, J.; Schwartzberg, L.; Danso, M.A.; Miller, K.D.; Rugo, H.S.; Neubauer, M.; Robert, N.; Hellerstedt, B.; Saleh, M.; Richards, P.; et al. Phase III study of iniparib plus gemcitabine and carboplatin versus gemcitabine and carboplatin in patients with metastatic triple-negative breast cancer. J. Clin. Oncol. 2014, 32, 3840-3847. [CrossRef]

77. González-Martín, A.; Pothuri, B.; Vergote, I.; DePont Christensen, R.; Graybill, W.; Mirza, M.R.; McCormick, C.; Lorusso, D.; Hoskins, P.; Freyer, G.; et al. Niraparib in Patients with Newly Diagnosed Advanced Ovarian Cancer. N. Engl. J. Med. 2019, 381, 2391-2402. [CrossRef] [PubMed]

78. Sandhu, S.K.; Schelman, W.R.; Wilding, G.; Moreno, V.; Baird, R.D.; Miranda, S.; Hylands, L.; Riisnaes, R.; Forster, M.; Omlin, A.; et al. The poly(ADP-ribose) polymerase inhibitor niraparib (MK4827) in BRCA mutation carriers and patients with sporadic cancer: A phase 1 dose-escalation trial. Lancet Oncol. 2013, 14, 882-892. [CrossRef]

79. Vinayak, S.; Tolaney, S.M.; Schwartzberg, L.; Mita, M.; McCann, G.; Tan, A.R.; Wahner-Hendrickson, A.E.; Forero, A.; Anders, C.; Wulf, G.M.; et al. Open-label Clinical Trial of Niraparib Combined with Pembrolizumab for Treatment of Advanced or Metastatic Triple-Negative Breast Cancer. JAMA Oncol. 2019, 5, 1132-1140. [CrossRef]

80. Appleman, L.J.; Beumer, J.H.; Jiang, Y.; Lin, Y.; Ding, F.; Puhalla, S.; Swartz, L.; Owonikoko, T.K.; Donald Harvey, R.; Stoller, R.; et al. Phase 1 study of veliparib (ABT-888), a poly (ADP-ribose) polymerase inhibitor, with carboplatin and paclitaxel in advanced solid malignancies. Cancer Chemother. Pharmacol. 2019, 84, 1289-1301. [CrossRef] [PubMed]

81. Loibl, S.; O'Shaughnessy, J.; Untch, M.; Sikov, W.M.; Rugo, H.S.; McKee, M.D.; Huober, J.; Golshan, M.; von Minckwitz, G.; Maag, D.; et al. Addition of the PARP inhibitor veliparib plus carboplatin or carboplatin alone to standard neoadjuvant chemotherapy in triple-negative breast cancer (BrighTNess): A randomised, phase 3 trial. Lancet Oncol. 2018, 19, 497-509. [CrossRef] 
82. Diéras, V.; Han, H.S.; Kaufman, B.; Wildiers, H.; Friedlander, M.; Ayoub, J.-P.; Puhalla, S.L.; Bondarenko, I.; Campone, M.; Jakobsen, E.H.; et al. Veliparib with carboplatin and paclitaxel in BRCA-mutated advanced breast cancer (BROCADE3): A randomised, double-blind, placebo-controlled, phase 3 trial. Lancet Oncol. 2020, 21, 1269-1282. [CrossRef]

83. Han, H.S.; Diéras, V.; Robson, M.; Palácová, M.; Marcom, P.K.; Jager, A.; Bondarenko, I.; Citrin, D.; Campone, M.; Telli, M.L.; et al. Veliparib with temozolomide or carboplatin/paclitaxel versus placebo with carboplatin/paclitaxel in patients with BRCA1/2 locally recurrent/metastatic breast cancer: Randomized phase II study. Ann. Oncol. 2018, 29, 154-161. [CrossRef]

84. de Bono, J.; Ramanathan, R.K.; Mina, L.; Chugh, R.; Glaspy, J.; Rafii, S.; Kaye, S.; Sachdev, J.; Heymach, J.; Smith, D.C.; et al. Phase I, Dose-Escalation, Two-Part Trial of the PARP Inhibitor Talazoparib in Patients with Advanced Germline BRCA1/2 Mutations and Selected Sporadic Cancers. Cancer Discov. 2017, 7, 620-629. [CrossRef] [PubMed]

85. Litton, J.K.; Hurvitz, S.A.; Mina, L.A.; Rugo, H.S.; Lee, K.-H.; Gonçalves, A.; Diab, S.; Woodward, N.; Goodwin, A.; Yerushalmi, R.; et al. Talazoparib versus chemotherapy in patients with germline BRCA1/2-mutated HER2-negative advanced breast cancer: Final overall survival results from the EMBRACA trial. Ann. Oncol. 2020, 31, 1526-1535. [CrossRef] [PubMed]

86. Litton, J.K.; Scoggins, M.E.; Hess, K.R.; Adrada, B.E.; Murthy, R.K.; Damodaran, S.; DeSnyder, S.M.; Brewster, A.M.; Barcenas, C.H.; Valero, V.; et al. Neoadjuvant Talazoparib for Patients with Operable Breast Cancer with a Germline BRCA Pathogenic Variant. J. Clin. Oncol. 2020, 38, 388-394. [CrossRef]

87. Miller, K.; Tong, Y.; Jones, D.R.; Walsh, T.; Danso, M.A.; Ma, C.X.; Silverman, P.; King, M.-C.; Badve, S.S.; Perkins, S.M. Cisplatin with or without rucaparib after preoperative chemotherapy in patients with triple negative breast cancer: Final efficacy results of Hoosier Oncology Group BRE09-146. J. Clin. Oncol. 2015, 33, 1082. [CrossRef]

88. Drew, Y.; Ledermann, J.; Hall, G.; Rea, D.; Glasspool, R.; Highley, M.; Jayson, G.; Sludden, J.; Murray, J.; Jamieson, D.; et al. Phase 2 multicentre trial investigating intermittent and continuous dosing schedules of the poly(ADP-ribose) polymerase inhibitor rucaparib in germline BRCA mutation carriers with advanced ovarian and breast cancer. Br. J. Cancer 2016, 114, 723-730. [CrossRef] [PubMed]

89. Durmus, S.; Sparidans, R.W.; van Esch, A.; Wagenaar, E.; Beijnen, J.H.; Schinkel, A.H. Breast cancer resistance protein (BCRP/ABCG2) and P-glycoprotein (P-GP/ABCB1) restrict oral availability and brain accumulation of the PARP inhibitor rucaparib (AG-014699). Pharm. Res. 2015, 32, 37-46. [CrossRef]

90. Simmons, A.D.; Nguyen, M.; Pintus, E. Polyclonal BRCA2 mutations following carboplatin treatment confer resistance to the PARP inhibitor rucaparib in a patient with mCRPC: A case report. BMC Cancer 2020, 20, 215. [CrossRef]

91. FDA. Grants Accelerated Approval to Rucaparib for BRCA-Mutated Metastatic Castration-Resistant Prostate Cancer. Available online: https://www.fda.gov/drugs/fda-grants-accelerated-approval-rucaparib-brca-mutated-metastatic-castrationresistantprostate (accessed on 15 July 2021).

92. Brill, E.; Yokoyama, T.; Nair, J.; Yu, M.; Ahn, Y.R.; Lee, J.M. Prexasertib, a cell cycle checkpoint kinases 1 and 2 inhibitor, increases in vitro toxicity of PARP inhibition by preventing Rad51 foci formation in BRCA wild type high-grade serous ovarian cancer. Oncotarget 2017, 8, 111026-111040. [CrossRef]

93. Chen, C.-C.; Feng, W.; Lim, P.X.; Kass, E.M.; Jasin, M. Homology-Directed Repair and the Role of BRCA1, BRCA2, and Related Proteins in Genome Integrity and Cancer. Annu. Rev. Cancer Biol. 2018, 2, 313-349. [CrossRef]

94. D'Andrea, A.D. Mechanisms of PARP inhibitor sensitivity and resistance. DNA Repair 2018, 71, 172-176. [CrossRef]

95. Adam, A.M.A.; Altalhi, T.A.; El-Megharbel, S.M.; Saad, H.A.; Refat, M.S. Using a Modified Polyamidoamine Fluorescent Dendrimer for Capturing Environment Polluting Metal Ions $\mathrm{Zn}^{2+}, \mathrm{Cd}^{2+}$, and $\mathrm{Hg}^{2+}$ : Synthesis and Characterizations. Crystals 2021, 11, 92. [CrossRef]

96. Kondrashova, O.; Nguyen, M.; Shield-Artin, K.; Tinker, A.V.; Teng, N.N.; Harrell, M.I.; Kuiper, M.J.; Ho, G.Y.; Barker, H.; Jasin, M.; et al. Secondary somatic mutations restoring RAD51C and RAD51D associated with acquired resistance to the PARP inhibitor rucaparib in high-g e ovarian carcinoma. Cancer Discov. 2017, 7, 984-998. [CrossRef]

97. Bajrami, I.; Frankum, J.R.; Konde, A.; Miller, R.E.; Rehman, F.L.; Brough, R.; Campbell, J.; Sims, D.; Rafiq, R.; Hooper, S.; et al. Genome-wide profiling of genetic synthetic lethality identifies CDK12 as a novel determinant of PARP1/2 inhibitor sensitivity. Cancer Res. 2014, 74, 287-297. [CrossRef]

98. Quereda, V.; Bayle, S.; Vena, F.; Frydman, S.M.; Monastyrskyi, A.; Roush, W.R.; Duckett, D.R. Therapeutic Targeting of CDK12/CDK13 in Triple-Negative Breast Cancer. Cancer Cell 2019, 36, 545-558.e7. [CrossRef] [PubMed]

99. Belotserkovskaya, R.; Raga Gil, E.; Lawrence, N.; Butler, R.; Clifford, G.; Wilson, M.D.; Jackson, S.P. PALB2 chromatin recruitment restores homologous recombination in BRCA1-deficient cells depleted of 53BP1. Nat. Commun. 2020, 11, 819. [CrossRef] [PubMed]

100. Sun, C.; Yin, J.; Fang, Y.; Chen, J.; Jeong, K.J.; Chen, X.; Vellano, C.P.; Ju, Z.; Zhao, W.; Zhang, D.; et al. BRD4 Inhibition Is Synthetic Lethal with PARP Inhibitors through the Induction of Homologous Recombination Deficiency. Cancer Cell 2018, 33, 401-416.e8. [CrossRef] [PubMed]

101. Donati, B.; Lorenzini, E.; Ciarrocchi, A. BRD4 and Cancer: Going beyond transcriptional regulation. Mol. Cancer 2018, 17, 164. [CrossRef] [PubMed]

102. Shibata, A.; Moiani, D.; Arvai, A.S.; Perry, J.; Harding, S.; Genois, M.-M.; Maity, R.; van Rossum-Fikkert, S.; Kertokalio, A.; Romoli, F.; et al. DNA Double-Strand Break Repair Pathway Choice Is Directed by Distinct MRE11 Nuclease Activities. Mol. Cell 2014, 53, 7-18. [CrossRef] [PubMed]

103. Wang, Y.; Zhang, Y.; Du, Y.; Zhou, M.; Hu, Y.; Zhang, S. Emerging roles of N6-methyladenosine ( $\left.{ }^{6} \mathrm{~A}\right)$ modification in breast cancer. Cell Biosci. 2020, 10, 136. [CrossRef] [PubMed] 
104. He, J.; Fortunati, E.; Liu, D.-X.; Li, Y. Pleiotropic Roles of ABC Transporters in Breast Cancer. Int. J. Mol. Sci. 2021, 22, 3199. [CrossRef] [PubMed]

105. Aldrak, N.; Alsaab, S.; Algethami, A.; Bhere, D.; Wakimoto, H.; Shah, K.; Alomary, M.N.; Zaidan, N. Oncolytic Herpes Simplex Virus-Based Therapies for Cancer. Cells 2021, 10, 1541. [CrossRef]

106. Singh, D.D.; Han, I.; Choi, E.-H.; Yadav, D.K. CRISPR/Cas9 based genome editing for targeted transcriptional control in triplenegative breast cancer. Comput. Struct. Biotechnol. J. 2021, 19, 2384-2397. [CrossRef]

107. Singh, D.D.; Verma, R.; Tripathi, S.K.; Sahu, R.; Trivedi, P.; Yadav, D.K. Breast Cancer Transcriptional Regulatory Network Reprogramming by using the CRISPR/Cas9 system: An Oncogenetics Perspective. Curr. Top. Med. Chem. 2021, 21, 1. [CrossRef]

108. Singh, D.D.; Hawkins, R.D.; Lahesmaa, R.; Tripathi, S. CRISPR/Cas9 guided genome and epigenome engineering and its therapeutic applications in immune mediated diseases. Semin. Cell Dev. Biol. 2019, 96, 32-43. [CrossRef]

109. Pettitt, S.J.; Krastev, D.B.; Brandsma, I.; Dréan, A.; Song, F.; Aleksandrov, R.; Harrell, M.I.; Menon, M.; Brough, R.; Campbell, J.; et al. Genome-wide and high-density CRISPR-Cas9 screens identify point mutations in PARP1 causing PARP inhibitor resistance. Nat Commun. 2018, 9, 1849. [CrossRef] 